\title{
ENDOCRINOLOGY:
}

\author{
The BULLETIN of the ASSOCIATION for the \\ STUDY of INTERNAL SECRETIONS
}

\section{OCTOBER-DECEMBER, 1918}

\section{CYCLIC CHANGES IN THE INTERSTITIAL CELLS OF THE OVARY AND TESTIS IN THE WOODCHUCK (MARMO'TA MONAX)}

\section{Andrew T. Rasmussen}

(From the Departments of Histology and Embryology, and of Physiology,

Cornell University, Ithaca, New York; and The Institute of Anatomy, University of Minnesota, Minneapolis, Minnesota)

Four plates (36 figures)

\section{CONTENTS}

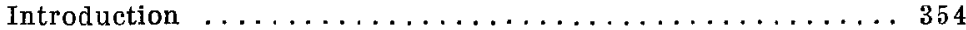

Cyclic changes in the interstitial cells of the ovary.......356

Historical ...................... 356

Present investigation $\ldots \ldots \ldots \ldots \ldots \ldots \ldots \ldots \ldots \ldots \ldots$

Material and methods............... 365

Results .................... 367

Condition during autumn........... 367

In the winter during hibernation......... 369

After hibernation, during rutting......... 371

Captivity and isolation during spring....... 375

During pregnancy and lactation......... 376

In midsummer $\ldots \ldots \ldots \ldots \ldots \ldots \ldots \ldots \ldots$

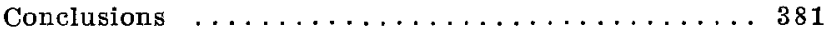

Origin of the interstitial cells of the ovary ... . . . . 381

Restudy of the interstitial cells of the testis.......... 387

Presence and behavior of mitochondria......... 387

The source of the pigment granules........... 390

Comparison of interstitial cells of the testis and ovary..... 391

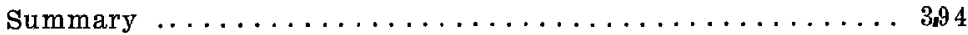

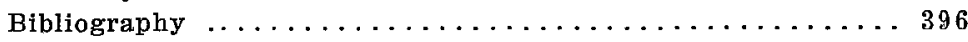




\section{INTRODUCTION}

The significance of the so-called interstitial cells found in the ovary and testis of many mammals and of some lower orders is still a much-debated subject. Since the introduction of the term "interstitial gland" by M. Bouin in 1900 with reference to the ovary and later applied to the testis by P. Bouin and P. Ancel ('03), these cells have received much attention in connection with the supposed internal secretory activity of the gonads, for which there is much evidence not only from experimental but also from strictly clinical sources and especially in the rapidly increasing field of organotherapy. One is particularly struck with the number of reports in current clinical literature on the more or less successful use of ovarian extracts and transplants in female disorders.

The question of cyclic changes in the interstitial cells of the testis and the relation of such periodicity to the various sexual phenomena, has been recently considered (Rasmussen '17) in a paper on the occurrence of a definite and well-marked seasonal hypertrophy of these elements in the male woodchuck. While similar changes have been reported in other animals, the various phases of atrophy and hypertrophy do not correlate well with any particular one of the other sexual phenomena. The interstitial cells of the testis are taken up again in this paper because a number of cytological details have been reinvestigated and because a comparison of the cyclic changes in these elements and the homologous cells of the ovary seemed desirable.

Essentially the same problems that are met with in the testis are encountered in the ovary, where similarly there are several tissues to which the endocrine function may be attributed and where there is much uncertainty as to the exact role played by each of the morphological components.

Of the many lines of inquiry followed in working with the interstitial cells of the ovary, a number stand out rather prominently; namely, comparative investigation as to their presence and relative abudance in the adult of different species, their morphological alteration during various periods of life as correlated with the sexual cycle, the effects of ovarian extirpation and transplantation, and their origin. The effects of $\mathrm{X}$-rays 
and of ovarian extracts together with histological findings in the ovary in various functional and developmental disorders, have also yielded many suggestive facts. It is not the purpose here to analyze the mass of literature that has necessarily accumulated since this has been done at various intervals and from various points of view in many papers of which the more recent ones are those by Anna Schaeffer ('11), Van der Stricht ('12), Pardi ('14a, '14b), Aschner ('14), Kingsbury ('14), Firket ('14) (best review of literature on non-mammalian forms). O'Donoghue ('16) (on marsupials), and Boring and Pearl ('17) (on birds). The publications by Tandler and Grosz ('13), Biedl ('13), Blair Bell ('16) and Falta ('16) may also be mentioned.

In regard to the presence or absence of interstitial cells in the ovary of adult mammals, it may be well to call attention to the fact that of more than one hundred species so far examined-of which Fraenkel ('05) and Anna Schaeffer ('11) alone investigated eighty-one-fully fifty per cent. are said to have none. In many of the species reported as not possessing interstitial cells during adult life, it is known that these elements may be plentiful in earlier stages of development. In some orders, e. g. Ungulata, they are rarely found; while in others, e. g. Rodentia, they are nearly always present. There may be considerable variation in closely related forms. In several cases there is disagreement among workers as to the presenee of these cells in the ovary. This variation in opinion is primarily due to a difference as to what constitute interstitial cells and hence an interstitial gland. Falta ('16, p. 370) states explicitly that in women we understand by "interstitial gland" a cell complex that develops from the theca interna of atretic follicles. Many do not, however, agree that these hypertorphied cells are comparable to typical interstitial cells found in the stroma in many other mammalian ovaries.

A second source of error in conclusions drawn from the examination of a few specimens of a given species is the more or less periodic change which the interstitial cells may undergo in animals, so that at certain times they are very inconspicuous and may be largely or even entirely overlooked in preparations stained by ordinary means; while at other times, usually related 
to active stages in the sexual cycle, they are easily detected. A failure to recognize the possibility of such fluctuations is undoubtedly responsible for some of the disagreement.

The primary object of this paper is to describe such variations in the interstitial cell content of the ovary of an animal, the woodchuck (Marmota monax), which has a single sexnal cycle per year, the successive cycles being interrupted by about four months of profound dormancy so that there is no overlapping of any of the phases. The latter point is of much advantage since it is obviously very difficult to make reliable deductions where structures developed in one phase are carried over to the same or some other phase of the following cycle or cycles. The fact that this animal becomes reduced in weight and exists for months without food and with a rectal temperature of $6^{\circ} \mathrm{C}$. to $15^{\circ} \mathrm{C}$, when normally in the active state the body temperature is in the neighborhood of $37^{\circ} \mathrm{C}$., and with all the physiological processes enormously reduced, should also present a situation that might throw some light on the behavior of the interstitial cells under modified functional conditions.

The bearing of these observations upon the problem of the significance of the interstitial cells naturally rests upon the assumption, generally accepted, that functional activity is correlated with structural changes, although it has not been proved that hypertrophy of these cells corresponds to increased secretory activity upon their part. One must agree with Gley ('17, p. 212) that there is a pressing need for physiological studies testing this assumption.

\section{CYCLIC CHANGES IN THE INTERSTITLAL CELLS OF THE OVARY HISTORICAI,}

Because of the availability of material and the size, great abundance and uniform distribution of the interstitial cells of the ovary in the rabbit, this animal has been used more than any other species in investigations of morphological variations in these elements. However the earliest record of such changes is generally attributed to MacLeod (' 80 ) who found that in the mole the lateral and greater portion of the ovary, which represents the medullary portion of the typical mammalian ovary and is separated from the cortical tissue by a distinct groove at certain seasons of the year, is minimal in June. By the last of October the entire ovary has increased to five times its former 
size and the lateral portion which now constituted nine-tenths of the entire organ was much darker in color and consisted of medullary cords separated by great masses of interstitial cells which were responsible for the enlarging of the ovary. During this increase in the interstitial cells, follicles had been developing and were beginning to undergo atresia. No information is given as to when atrophy takes place. This must occur some time before the following June. While he examined the ermine and bat, no changes in the interstitial cells of these animals are mentioned.

Leydig ('57) noted that the division of the mole ovary into two superimposed parts did not exist at all seasons of the year since he did not find it so in June, but gives no further details; while Wagner ('79), in a description of the modifications going on in the ovary periodically with the recurrence of rut and gestation, considered the medullary portion of the ovary of the mole to be a corpus luteum.

According to Tandler and Grosz ('11), the mole litters during the last of April and first of May-fertilization having taken place in March when spermatozoa are abundant in the male. An increase in the interstitial cells of the ovary thus takes place months after the rutting season. In the testis of the mole of this species, Tandler and Grosz ('11), found a similar hypertrophy of the interstitial cells. This reaches a maximum in August, or about two months ahead of the corresponding changes in the female. In the testis also these elements are minimal during the rutting season.

A suggestion of periodicity in the interstitial cells was made by Paladino ('87), who describes a continual degeneration and regeneration of the ovarian parenchyma (including the interstitial cells) and noted that these processes are not going on at a uniform rate at all ages or even in the adult, being, in the latter case, especially marked at the time of heat and pregnancy, during which times he also noted, especially near the hilus, marked down-growths of the germinal epithelium into the medulla and other evidences of regeneration apparently compensatory for the marked degeneration that had gone on. He worked on the pig, horse, cow, sheep, goat, rabbit, guineapig, cat, dog and man and apparently found the above to be true in general.

Child ('97) found the stroma cells of the ovary of pregnant rabbits and of a pregnant dog to be much hypertrophied and to possess a centrosome and sphere-structures not demonstrable by this author in these cells in adult rabbits at other times except shortly after parturition. He could not find a centrosome and sphere in these elements in the cat or in the white rat at any time, although he noted that at the time of preg- 
nancy the stroma cells undergo hypertrophy somewhat the same as in the rabbit and dog. Child is evidently describing changes in what are now generally termed interstitial cells for he found intermediate stages between spindle-shaped stroma cells and polyhedral cells with a spherical nucleus. He states that in non-pregnant rabbits the stroma consists largely of the long spindle-shaped cells with deep staining nuclei and boundaries that are difficult to make out; while the ovaries of pregnant rabbits (and dog) contain relatively few of these spindleshaped stroma cells, but instead a great many of the larger cells with abundant cytoplasm, one or two distinct eentrosome and a vesicular nucleus écentric in position.

Child raises the question as to what is the relationship of these ovarian changes to pregnancy. A number of subsequent investigators have attempted to throw light on this particular question, using mostly the rabbit as material; yet not only does the question remain unanswered, but there is great diversity of opinion as to what changes if any, in these (interstitial) cells, actually do occur during pregnancy, as the following review of the literature will show.

Lane-Claypon ('06) found in the rabbit an increase in the size of the interstitial cells of the ovary with the progress of pregnancy, reaching a maximum at about the twenty-second day. They increase in diameter from 17 to 32 micra or about five times in volume. The whole ovary increases, which is fully accounted for by the hypertrophy of the interstitial cells. Commencing a few days before parturition, they diminish again, reaching a minimum about six weeks later, which is maintained till the next pregnancy supervenes.

Pardi ('14b) similarly found in the rabbit an increase in size and in lipoid content of the interstitial cells during the major portion of pregnancy, those in the virgin being 22 to 23 micra in diameter while in the pregnant animal they increase to 27 or 28 micra. This increase is solely in the cytoplasm, according to this author. The nucleus remains unchanged. There may also be an increase in number by a transformation of stroma-cells. The whole ovary increases in size directly with these changes.

An increase in the lipoids during pregnancy has been recorded by Ciulla ('09) and Ciaccio ('10). The latter author from a study of the eat, dog, rat and guinea pig, in addition to the rabbit, also thinks that there may be an increase in number of interstitial cells by a hypertrophy of stroma elements.

Others have failed to find any striking change during pregnancy or other phases of the sexual cycle in the rabbit. Limon ('02) maintains that when once formed they remain un- 
changed. Allen ('04) says that a description of the interstitial cells in a six months old virgin rabbit applies equally to early pregnancy and he is inclined to think from an examination of a number of adult rabbits that pregnancy makes no difference in the number of atretic follicles (from which interstitial cells may be derived). Zalla ('07), who worked on the rabbit as well as on ten other species, could not establish any appreciable or constant change in the interstitial cells during pregnancy. Regaud and Dubreuil ('08), while not denying the possibility of a slight increase during gestation in the rabbit, did not find a regular correlation between degrees of hypertophy of the interstitial cells and duration of pregnancy, all stages of variation in these elements being encountered at any particular stage of pregnancy. They found later ('09) that there is a tendency for this tissue to develop during the spring months.

And finally the third possibility, namely, that the interstitial cells decrease during pregnancy, has been strongly defended for the rabbit, as well as for other animals, by Aschner ('14), who maintains that the interstitial cells of the ovary increase till rut, being maximal at the beginning of pregnancy, and that there is a distinct retrogression as corpora lutea develop. The next period of follicular growth and increased atresia is accompanied by an increase in the interstitial cells.

Montuoro ('03) found a decrease in the amount of lipoids in the interstitial cells during pregnancy in the rabbit; but Pardi ('14b) argues that this must be due to faulty technique, Montuoro having used osmic acid and paraffin imbedding, resulting in a loss of some of the more soluble lipoids.

The rabbit has been used for many other lines of research upon this subject, but the above is believed to be a fairly complete résumé of the particular phase with which we are here concerned. It is evident that in spite of the amount of work done on this supposedly very favorable animal, there is still great need for a careful checking up of this entire line of investigation on this as well as on other species. A number of other animals have received some attention and to the results obtained we may briefly refer.

From an examination of the ovaries of $250 \mathrm{dogs}$, Aschner ('14) found during pregnancy a similar decrease in the interstitial cell to that described by him in connection with the rabbit. He disagrees radically with Fraenkel ('05, '11), Aimé ('07), Schaeffer ('11) and others who claim that there are no interstitial cells in the ovary of the adult dog. It was noted above, however, that Child ('97) described the ovarian stroma of a pregnant dog as containing polyhedral cells essentially similar to those in the rabbit. While Ciaccio ('10) eites the dog as an example of an animal in which the interstitial gland, 
represented only by scattered elements, shows marked hypertrophy during pregnancy and moderate infection and intoxication. Aschner explains that the discrepancy in the observations between himself and Fraenkel, etc., may be accounted for on the grounds that these cells are readily changed by disease, inanition, poisons and by defects in the glands of internal secretion. These conditions, he claims, may so decrease the fatty content of the ovary that Sudan III gives no stain in frozen sections. In reviewing the phylogenetic and ontogenetic conditions, he concludes that the higher one goes in the animal scale the more the corpus luteum dominates and the more the interstitial cells are depressed. Such an inverse proportional development of the interstitial gland and corpus luteum was also noted in a number of animals by Cesa-Bianchi ('07a) and Anzilotti ('09), and calls to mind the classification of mammals proposed by Bouin and Ancel ('09), who place in one group animals in which ovulation is spontaneous so that at definite periods there develop one or more corpora lutea regardless of fertilization. Such animals do not have an interstitial gland. In the other group they place animals in which corpora lutea develop only at coitus and hence possess only corpora lutea of pregnancy; but they have an interstitial gland which takes the place of the periodic corpora lutea. Exceptions to this rule have, however, been recorded. This point is discussed by Kingsbury ('14), Loeb ('17) and others and need not be further considered here.

In marsupials O'Donoghue ('16) finds that subsequent to ovulation the interstitial cells and their nuclei undergo hypertrophy, although they never become as large as the cells of corpora lutea. At this time they appear very epithelioid and glandular, and in consequence he regards them as masses of secretory tissue. The maximal enlargement is reached about the time the corpora lutea become fully formed and appear to remain active longer than the luteal cells, being in an active condition long after birth of the young and after the corpora lutea have commenced to decline.

Athias ('16) says that in the guinea pig the interstitial cells increase at puberty and gestation at the expense of atretic follicle. Although Loeb ('17, p. 300) states that just piror to ovulation a sudden simultaneous degeneration of all but the smallest follicles sets in and that the theca interna of atretic follicles is strongly developed five to seven days after ovulation, he regards the ovary of the normal adult guinea pig as not possessing true interstitial cells. In earlier publications ('11, p. 341 and '14, p. 39) he speaks of their being represented only by small shrinking connective tissue cells of the theca interna filling the place of lost parts of the follicles which are in process 
of atresia. In the most recent paper ('18, p. 48) we find the unqualified statement that typical interstitial cells are not present in the ovary of the normal guinea pig. This divergence of opinion is extreme when, we consider that Limon ('02, p. 185) claims that interstitial tissue (composed of interstitial cells) is abundant in the ovary of the adult guinea pig and describes them (p. 165) as being 12 to 15 micra in diameter with a nucleus of 4 to 5 micra in diameter and as forming dense cords and compact masses of cells. Fraenkel ('05, p. 500) says in connection with the four types of ovaries as regards the nature and arrangement of the interstitial cells :

"Den Haupttypus habe ich in Uebereinstimmung mit Limon oben beschrieben. Der grösste Theil des Ovariums ist von diesem Gewebe eingenommen, welches durch Bindegewebsstränge, die mit Rinde und Hilus communiciren, in Läppchen und Fächer eingetheilt ist. Die Zellen liegen sehr dicht, sind dunkel gekörnt oder enthalten feinste Tröpfchen. Ihn repräsentiren am schönsten die Nager, wie Kaninchen, Meerschwein, die Meerkatze, ferner unter den Beutlern die Petro-und Onychogale."

Bouin and Ancel ('09, p. 465) from their own investigations include the guinea pig with the rabbit, mouse and cat as examples of animals with an interstitial gland in the ovary in contrast with women, primates, dog, mare, sow and cow, which possess no interstitial gland but instead periodic corpora lutea. A number of others have described interstitial cells in the guinea pig ovary specially in connection with cytological studies; but it is not always clear that they have reference to adult animals - the only ones admissible in this discussion.

The technique to be employed in the investigation reported here was tried out on guinea pig ovaries and certainly there are many comparatively large cells (10 micra and more in diameter) with spherical or nearly spherical nueleus ( 5 micra in diameter) and with lipoid-laden cytoplasm-the three principal criteria of interstitial cells-not only in the theca interna of atretic follicles but also in groups in the stroma between follicles and about blood vessels in the medullary portion of ovaries of an adult animal. It is difficult to see how these can be ruled out from the so-called interstitial cell category. At least-and this is the reason for dwelling upon this point-these are what is now in general meant by interstitial cells and this paper deals with such elements. As for differentiating them from the ordinary stroma elements of the guinea pig ovary, better differentiation was obtained with acetic-osmic-chromic fixer and sodium alizarinsulphonate and crystal violet stain on guinea 
pig than on wood chuck material. It may still be objected that these groups of cells in the stroma proper are the remains of atretic follicles. O'Donoghue ('16), for example, thinks that during degeneration of follicles some of the theca cells merely pass through a stage in which they resemble interstitial cells, and that the interstitial cells constitute a tissue sui generis. To this one can only reply in the words of Kingsbury ('14, p. 73): "So consistently has this mode of thecal origin of the interstitial cells of the adult ovary been supported by the observations of nearly all who have devoted careful study to this phase of the subject that it may be accepted as clearly proven." As to whether these cells collectively constitute a gland is a separate question. One must agree with Loeb ('17) and many others that there is a lack of clearness in the definition of interstitial gland of the ovary, to say nothing of its specific function.

Since a large number of investigators considers that the hypertrophied cells of the theca interna of atretic follieles in women are homologous to the interstitial cells of the stroma in animals, a consideration of the human ovary must be included in this review if it is to be reasonably complete; for an increase in atresia and the accompanying hypertrophy of the theca interna cells of involved follicles, has been described in the human ovary during pregnancy by De Sinety ('77), Cohn ('03, '09), Böshagen ('04), Pinto ('05), Seitz ('06), Basso ('06), Walwart ('07, '08), Fellner ('09), Greggio ('10), Pottet ('10), Wolz ('12), Meyer ('13), Keller ('13), Pardi ('14b) and Schottländer ('14). While all these authors do not agree as to the significance of this hypertrophy, most of them consider it an expression of secretory activity. Wallart and Schottländer maintain that here is a similar increase during menstruation in human subjects. Fraenkel ('05, '11), Aimé ('07), Bayer ('08), Bouin and Ancel ('09), Schaeffer ('11), Foster ('17) and others can, however, see nothing in the adult human ovary that could be considered an interstitial gland, although Fraenkel ('05) describes an enlargement of the theca cells during pregnancy. Aschner ('14) from an examination of seventyeight cases concluded that the interstitial cells are not only much less in evidence in the adult and even at puberty than at birth, but decrease still farther with the appearance of corpora lutea-a general principle that this author finds applicable to a number of different animals as already noted. He considers, however, that the interstitial tissue constitutes a distinct morphological structure.

The whole subject is fraught with uncertainty and conflicting opinion. This is probably illustrated nowhere else so well as in the case of the human subject. To illustrate this point, although not strictly pertaining to cyclic changes a number of 
recent opinions may not be out of place. Thus Kingsbury ('14), while finding no difficulty in demonstrating interstitial cells in the human ovary (presumably adult), regards them as transitory elements coming from and returning to ordinary stroma cells, and finds it difficult to escape from the conclusions of Fraenkel ('05, '11) that a tissue so inconstant in its presence, even in mammals, does not deserve the dignity of being termed a gland. This is the opinion also of O'Donoghue ('16). Blair Bell ('16) greatly minimizes the importance of the interstitial cells, claiming that the gonads as a whole play only a subservient part in connection with a determination of secondary sexual characters and other internal secretory functions ascribed by many to this organ and in particular to the interstitial tissue. Falta ('16), on the other hand, says that the function of the interstitial gland in man is today already so sharply delimited and is concerned with functions so important and extensive in influencing the conformations of the body, that it is hard to believe that so important an organ is absent in women.

In contrast to the uncertainty in regard to cyclic ehanges in the interstitial cells of the ovary of many of the forms so far discussed. is the marked annual periodicity described in a number of hibernating animals.

Cesa-Bianchi ('07b), from an examination of serial sections of more than one hundred ovaries of the bat, found that in late March and early April, immediately after the hibernating period, the ovary increases to several times its former size, due to a great increase in interstitial cells, which become completely filled with lipoid and pigment.

In May and June when nearly all females contain foetuses, the ovary is still large and yellow but follicles are so reduced in number that one would hardly recognize the organ as an ovary. The interstitial cell masses have become lobulated rather than columnar. This condition prevails during the remainder of the summer.

Just before bad weather sets in in the autumn and before dormancy intervenes, the interstitial cells rapidly decrease and finally well into the winter season have nearly disappeared. The ovary loses its yellow color and diminishes in volume.

It is to be remembered that in the bat copulation takes place in the autumn; but fertilization and segmentation of the ovum does not occur. until after waking up in the spring, when hypertrophy of the interstitial cells again occurs.

Similar changes, except to a less degree, were observed by this author in the badger, squirrel, marmot and hedgehog.

Van der Stricht ('12) noted an increase in the number and size of interstitial cells of the ovary in the bat during winter and particularly in the spring after waking up. The nucleus 
of these cells becomes slightly larger and stains less densely. The cells become arranged in acini-like groups which are especially numerous and conspicuous during second maturation and ovulation and persists during the summer to a lesser and lesser degree as autumn is approached. In September and Oetober such groups are no longer in evidence, the interstitial cells having materially decreased.

Aschner ('14) states that a decrease in the fatty content and the interstitial cells of the ovary of the hedgehog and tenrec (Centetes ecaudatus) takes place during hibernation, while an increase occurs in the spring. This investigator suggests that the large amount of interstitial tissue in the ovaries of rodents, insectivores, bats, etc., may be related to the fertility of these animals, since a great many follicles are produced and hence much atresia follows. Paladino ('87) similarly noted that degeneration and regeneration in the ovary is more extensive in the more prolific animals.

Only two references were found which dealt with the interstitial cells of the ovary of a hibernating animal of this country. In connection with the subject of hibernation and the pituitary body, Cushing and Goetsch ('15) incidentally report that in the ovaries of two hibernating woodchucks killed in February, there was a small amount of interstitial tissue, but no interstitial cells were definitely recognized. There were no mature follicles. In an animal sacrificed late in March, one ovary contained several corpora lutea and but little interstitial substance containing a few immature follicles. In a fourth animal, which was sacrificed early in May and which had been in captivity all winter and awake several weeks, there were fully formed follicles and one corpus lutenm and an increase in the interstitial cells.

Drips ('17), while studying primarily the corpus luteum of the spermophile (striped gopher, thirteen-lined ground-squirrel or technically Citellus tridecemlineatus), noted that the interstitial cells were most conspicuous during early pregnancy and least noticeable just before hibernation took place.

On the whole it appears that an observable increase in the size and possibly in the number of interstitial cells of the ovary of some animals oceurs more or less synchronously with rutting and may persist to some extent during pregnancy. There is, however, so much disagreement in connection with several of the species studied that it is impossible to draw conclusions as to the extent of such changes. It is evident that a serious obstacle in the way of accuracy in judging of the degree of hypertrophy or atrophy in the interstitial tissue in most animals, is the irregular and scattered arrangement of the cells. Even in the rabbit, where they are most regularly arranged, there are 
great differences in the recorded observations. There is, in consequence, a necessity for much detailed cytological work along this line before it is clear just how extensive cyclic changes occur and with which phases of the general sexual cycle such alterations are related.

\section{PRESENT INVESTIGATION}

\section{Material and Methods}

This report is the result of an investigation of 144 (72 pairs) of ovaries taken from woodchucks killed at varions seasons of the year, the technique employed being the same as that used on the interstitial cells of the testis (Rasmussen '17).

All the animals except two were captured in the vicinity of Ithaca, New York. The ovaries of the two exceptions were obtained from Dr. T. G. Lee of the University of Minnesota. They had been collected somewhere south of Minneapolis several years ago and were well fixed in Zenker's fluid and preserved in alcohol. I take this opportunity to thank him for this material which was especially valuable because both the animals from which it was obtained were pregnant, one containing six very young foetuses (uterine enlargements being $8 \mathrm{~mm}$. to $9 \mathrm{~mm}$. in diameter) and the other one seven older foetuses 40 $\mathrm{mm}$. to $45 \mathrm{~mm}$. in length.

The 72 animals involved were killed at intervals so that a larger number were sacrificed at the more critical periods. The number killed in the respective months of the year are as follows: 1 in January, 7 in February, 6 in March, 12 in April, 9 in May, 1 in June, 13 in July, 10 in August, 1 in September, 4 in October, 2 in November and 6 in December. While most of those used between the months of October and the following March had necessarily been kept in captivity from the preceding September, a few controls were obtained directly from the normal habitat in February and March. This is obviously important because these animals do not breed in captivity, as far as our experience goes, and unless material is available from animals that have not been kept for any length of time in captivity, one would not be justified in concluding that the findings represent the conditions as they exist normally. All the illustrations on the ovary accompanying this paper except figures 8 and 17 are from animals killed either in the field, im- 
mediately upon being brought to the laboratory or at most two days after being captured. After March and until October material was available again directly from the normal habitat.

The artificial burrows in which nearly all the animals were allowed to hibernate in captivity have been previously described (Rasmussen '15). These burrows are such that the conditions are essentially the same as in the natural ones and in them woodchucks have successfully become dormant for a number of years. Five animals involved were shipped to the Institute of Anatomy, University of Minnesota, where they were kept in a small room in which the temperature was kept be. tween $-5^{\circ} \mathrm{C}$. and $+13^{\circ} \mathrm{C}$ : Only oceasionally and then for only a few hours did the temperature go below $0^{\circ}$. C. and above $+10^{\circ} \mathrm{C}$. during the hibernating period.

In addition to the technique used on the testis as referred to above, fifteen animals were injected with neutral formalin and potassium dichromate as advised by Cowdry ('16b) and quoted by Scott ('16). Perfusing the animal with Locke's solution sufficiently to produce a degree of edema in the ovaries before the fixer is allowed to enter the vascular system was found especially useful in opening out the dense stroma and separating the individual cells, making them stand out more prominently. This material as well as that fixed with the acetoosmic-chromic fixer used on the testis, when stained with acid fuchsin and methylgreen according to the directions given by Cowdry, gave the most instructive cytological picture by bringing out in sharp contrast mitochondria and other granules in the cytoplasm. If sections from material fixed in solutions containing osmic acid are passed rapidly through the higher alcohols and clearers, covered with a thin layer of xylol-balsam and using no cover glass, but allowing the balsam to dry quickly, the lipoid granules darkened with the osmic acid may be retained. If very much lipoid is present, other cytoplasmic granules are masked too much and it is then better to allow the large lipoid granules to be dissolved out. In this case a cover is used. The lipoid then appears as vacuoles. It will be interesting to see how the acid fuchsin and methylgreen stain will last in uncovered preparations since it is known to fade in a year or two ordinarily when covered. 
While in most cases it was necessary to eut both ovaries into pieces to provide material for the various fixers, a sufficient number of whole ovaries were fixed to provide for complete serial sections representative of the different seasons of the years. Sections were cut 3,5 and 10 micra in thickness. For eytological details the thinnest sections were necessary.

\section{Results}

Conditions during autumn.-From September to November the ovaries are small, each varying from .0005 to .0015 per cent. of the net body weight. During this period there is a slight increase in size as winter is approached, due largely to growth of follicles. There are no corpora lutea present. Only occasionally is there any evidence of such structures having been present, the evidence being the presence of large pigmented cells in an area composed mostly of connective tissue still more or less radially arranged. Follicles in nearly all stages of development are present (Fig. 1). Since both ovaries are alike in practically every case during this and other periods of the year when no corpora lutea are present, the percentage weights given refer in all cases to a single ovary.

In the stroma both of the cortex and medulla are many cells varying in size from 4 to 13 micra in average diameter (most of them being from 5 to 9 micra), containing a round vesicular nucleus from 3.8 to 7 micra (mostly 5 micra) in diameter, with a variable amount of cytoplasm as shown in figure 24 . The cytoplasm is rarely firee from one or more comparatively large lipoid granules that darken with osmic acid. These are the socalled interstitial cells as distinguished from the ordinary. stroma cells which have an elongated more or less spindleshaped granular nucleus and only a small tip of cytoplasm (containing a few mitochondria) at each end.

The variation in size and shape of the interstitial cells and the lipoid (shown in black or as vacuoles) and mitochondrial content (red) are shown in figure 24. The size of the cells varies directly with the lipoid content. There are only a few cells with as much lipoid as is shown in cell e of this figure. As a result it is difficult to give an adequate idea of the amount of interstitial tissue in a general view. In figure 1, which is a photograph of a longitudinal section through an ovary of this 
period, the darker areas are due to the osmic acid of the fixer having blackened the lipoid of the interstitial cells. The amount of lipoid in this particular case is, however, greater than is usually the case at this time of the year. In many instances a photograph of this kind would show practically no dark areas in the stroma, but appear essentially as figure 7 , not because there are no interstitial cells but because each cell contains only a few lipoid granules and many sections through cells show none, as in cell $b$ of figure 24, and hence there is not enough contrast to show anything at so low a magnification. (X $71 / 2)$.

In the cortical portion of the ovary there are usually masses of interstitial cells closely associated with the follicles, occupying a triangular area on the hilus side of the follicle. Irregular rows and columns of cells are also found in regions between follicles. These have their long axis directed towards the hilum. The septa of ordinary stroma and the blood vessels undoubtedly are responsible for this arrangement. In the more central part of the ovary, the interstitial cells are in close proximity to the blood vessels and medullary cords, often forming a wall about these structures. This relationship to the vascular system and medullary cords is shown in figure 10, which, however, is a photograph of a later stage when the interstitial cells have much enlarged. The interstitial cells constitute the dark areas. In the center of many of the interstitial cell masses is a medullary cord, not seen very plainly in the photograph. The close association of interstitial cells with the blood and lymph vessels has been described by many authors. Some have taken this as evidence of the secretory activity of these cells.

Mitochondria are packed closely in the scanty protoplasm about the nucleus and between the large lipoid granules. Nearly all mitochondria are spherical as may be seen in figure 24 . In a preliminary report of this work (Rasmussen '18) it was stated that there were also short rods. It appears from a closer study of the best fixed material that these rods can usually be resolved into two granules. Still there are a few very short ones, from $1 \frac{1}{2}$ to 2 times as long as they are wide, each ' of which appears to be a single body. 
Mitochondria have been described in the interstitial cells of a number of animals by Mulon ('10), Athias ('11, '12), Levi ('13), Cattaneo, and Pardi ('14b), usually as rods and granules. Padri in the rabbit indicates only 6 to 8 rods to 100 or 200 round mitochondria.

In the woodchuck the mitochondrial content appears to vary directly with the size of the cells during this stage.

The nucleus is usually somewhat ecentric, nearly spherical, with a very attenuated chromatin network and one or two distinct nucleoli. There are some elongated cells, as figure $24 \mathrm{a}$, in which the nucleus is also elongated. These are evidently transitional stages in the formation of typical interstitial cells from the ordinary stroma cells or cells that appear to have migrated from the germinal epithelium as will be dis. eussed later. In these elongated cells the chromatin is more granular (not indicated in the figure because in the over fixation necessary to bring out mitochondria, the nucleus appears nearly homogenous with the acid fuchsin-methylgreen stain. The nucleus tends to vary in size directly with the size of the cell. In general this is also true of the nucleolus.

In winter during hibernation.-Hibernation commences in November and continues till some time in March. During this period, just as in the autumn, the ovary shows great individual variations in weight, varying from .0008 to .0023 per cent. of the net body weight. The average weight is about .0014 per cent. This range of variation is met with during all parts of the period, although the ovaries appear to constitute on the average a slightly greater proportion of the body weight toward the end of hibernation. But since during dormancy the body weight falls $1 / 4$ to $1 / 3$ of its original weight, this increase does not indicate an actual enlargement of the ovaries. Both ovaries of the same individual are strikingly alike. A section of a typical ovary representative of late hibernation is shown in figure 2. As is clearly evident by comparing this figure with figure 1, there is no follicular development during winter sleep. On the contrary, there is much atresia. Most of the large follicles and many of the smaller ones have become atretic and as usual the cells of the theca interna acquire lipoid 
and in other respects come to be indistinguishable from interstitial cells in other parts of the stroma. The conditions ale the same in animals taken directly from their normal habitat and in those kept in captivity.

Some of the interstitial cells during dormancy are slowly enlarging so that a number are 16 micra in average diameter. A few cells may be even larger, especially late in this period, but most are between 8 and 10 micra. The enlarging is due principally to an increase in the lipoid. As spring is approached there are a greater and greater number of cells containing as much lipoid as is shown in figure $24 \mathrm{e}$. By the last of February, as shown in figure 2 , the interstitial cell masses are noticeably more prominent than before hibernation commenced.

With an increase in the size and lipoid content of the interstitial cells during this period there is an increase in the number of mitochondria, and in the largest cells some of the mitochondria appear somewhat larger while no rods are evident. These large mitochondria may, therefore, only be the elongated ones that have assumed a spherical form. Levi ('13) in the guinea pig and other forms records an increase in the mitochondrial content with hypertrophy of these cells to a certain point and that they persist during fatty infiltration to an extreme degree. Athias ('11, '12), however, in both guinea pig and bats describes the mitochondria as being inversely in proportion to the lipoid, while Pardi ('12b) in the rabbit could see no difference with hypretrophy of the irterstitial cells during gestation.

The nucleus has enlarged, being from 4 to 8 micra in diameter (most of them being about 6 micra). The nucleoli tend to enlarge in about the same proportion.

There is therefore no sudden change in the interstitial cells with the onset of hibernation nor any decrease in the activity of these elements during dormancy as far as the criteria of amount of lipoid, number of mitochondria and size and prominence of the cells are concerned. The statements made in the literature that the interstitial cells of the ovary decrease during winter-sleep are in most cases based on the few observations made on hibernating animals in which the period 
just preceding and the early part of hibernation have not been carefully investigated and where the assumption has been made that since the interstitial cells are more prominent in the summer than in winter, that the decrease has taken place at the onset of hibernation. As we shall show later, in the woodchuck the decrease takes place during full activity in the summer, and as already indicated there is a slow but unmistakable increase in the interstitial tissue during lethargy although no food or water is available for several months. A general idea of the appearance of the stroma at the close of hibernation as compared with that preceding dormancy after a sharp nuclear stain is obtainable by comparing figure 16, which is from an animal killed in autumn, with figure 17, which is from an animal sacrificed March 18 within 48 hours after waking up. In the left hand portion of each figure are many interstitial cell nuclei which appear more or less round in contrast to the long, spindle-shaped nuclei of stroma cells (although there are intermediate forms). The round nuclei are much more prominent and in general somewhat larger in figure 17. These differences are reflections of the differences existing between the entire cells. The irregular distribution* of the interstitial cells in the woodchuck makes quantitative statements only of a very general character possible. In the bat it also appears (Van der Stricht '12) that the interstitial cells are minimal during September and October and that they tend to increase during winter.

Aschner ('14), it may be recalled, claims that in dogs the interstitial cells of the ovary are diminished by inanition. The type of inanition involved during hibernation appears not to produce such an effect in the woodchuck, at least.

In the spring after hibernation and during rutting and beginning pregnacy.-Immediately after. waking up from winter sleep (which in the vicinity of Ithaca, New York, usually occurs about the middle of March) the rutting season commences ard the ovaries enlarge rapidly due to a ripening of numerous follicles and to a rapid increase in size of all of the many interstitial cells that have remained comparatively small. Before the end of March the ovary may represent .0050 per cent. of the net body weight. The lipoids of many of the interstitial 
cells increase so that the mitochondria, which appear to have reached their limit in number, are crowded in between the large fatty granules as illustrated in figure $25 \mathrm{~b}$, where the lipoid is seen as vacuoles. Others have less lipoid and more cytoplasm rich in mitochondria as illustrated in figure 25 a, where the lipoid granules are represented in black. There are also intermediate forms.

During the early spring increase there appear in many of the larger cells additional granules somewhat larger in size than the mitochondria but having, as far as the technique here employed would indicate, very similar staining reaction. In figure 25, cell a contains three and cell b two such granules. They are best demonstrated in the material fixed in Meves' fluid. They may be of the nature of secretion granlues or they may be other lipoids sufficiently chromated to take the stain. That they are produced from mitochondria, as Mulon ('10) believes to be the case in regard to secretion-like granules in the interstitial cells of the rabbit ovary, is also possible. These granules will be further discussed later.

While females captured in April usually contain foetuses, some may be found not to have become pregnant as late as early in May. In these late cases extreme hypertrophy of the interstitial cells is found. This may be due to a prolonged rutting period, as would be suggested by the results obtained by Regaud and Dubreuil ('09) who found that prolonged cohabitation with the male produced a noticeable hypertrophy of the interstitial cells of the ovary in the rabbit.

The maximal development of the interstitial tissue encountered is shown in figure 3. This is from an animal shot in the field while chasing about with a male (which was also shot and found to possess testes with ripe spermatozoa and interstitial cells maximal) about six weeks after woodchucks were observed in general to become active that particular season. The great size of the ovary is apparent since it is reproduced at the same magnification as figures 1 and 2 and represents $.0085 \%$ of reduced body weight. Both ovaries were alike. Six ovaries representing this stage were obtained.

The abundance of interstitial cells may be judged from figure 4 which is an enlarged view of the area outlined in white in 
figure 3. The blackened lipoid granules, which serve to identify the interstitial cells, are here shown with greater contrast. A still higher view of a thinner section with a nuclear stain is shown in figure 18, which is directly comparable with figures 16 and 17. Many of the interstitial cells are over 20 micra in average diameter, containing a nucleus as large as 12 micra and nucleoli as large as 3 micra in diameter. The chromatin becomes more attenuated as the nucleus enlarges. Most of the cells are in the neighborhood of 16 micra and the nuclei about 8 micra in diameter. The size to which these cells may develop is shown in figure $26 \mathrm{~b}$. They are often arranged in irregular groups, the individual cells being poorly separated from each other, as illustrated in figure 26 a. The quantity of lipoid in the individual cell varies from an amount that fills completely the cell as in figure $25 \mathrm{~b}$ to relatively a few granules such as is shown in some of the cells in figure 26. The cells not completely filled with lipoid are by far the most numerous in these extreme cases. Such cells contain a correspondingly large number of fuchsinophile granules of various sizes as shown in figure 26. The smallest granules-evidently mitochondria-are greatly masked by the larger ones and are seen only in the best fixed material 3 micra, or less in thickness. The larger granules are more easily fixed and stained, being fairly clear in ovaries fixed in Zenker's fluid and preserved for several years in alcohol before being imbedded and stained with iron hematoxylin. In such preparations they appear essentially the same as the socalled secretion granules of neighboring lutein cells.

Various forms of granules have been observed in the interstitial cells of the ovary of several mammals by a number of investigators by employing copper hematoxylin, iron hematoxylin, and other stains. The fuchsinophile granules figured by Montuoro ('03) in the interstitial cells of the rabbit appear to be very similar to those here described. This author shows cells, containing very little fat, which are practically filled with such granules. He found the interstitial cells of older adults to be relatively richer in metaplasm, possibly due to a replacement of the fuchsinophil granules by fatty droplets such as evidently occurs in the woodchuck a little later when atrophy commences, as will be shortly explained. 
In figure 3 it will be noted that there is considerable atresia. In one very large atretic follicle and two adjacent smaller ones the intensely black color is due to the abundance of lipoid in the hypertrophied theca cells. The other smaller atretic follicles scattered throughout the ovary contain less lipoid. There is no essential difference between these hypertrophied theca cells and interstitial cells not related to follicles. The theca cells acquire lipoid more rapidly and tend to become somewhat larger in size. A medium-sized atretic follicle of this period is shown in the center of figure 22. The cytological details of the theca cells may be represented by figure 26 . The theea interna (T) can be distinguished from the surrounding stroma (IC) by its heavier lipoid content, indicated in black. There can be no mistaking of derivatives of the granulosa for hypertrophied theca cells in this case because the basement membrane (M) is still intact and within are a few remains of the atrophied granules as well as a fairly well preserved ovum and a little of the discus proligerous indenting the lower side of the egg membrane.

The similarity in appearance of interstitial and lutein cells has been commented on by many writers and especially by Van der Stricht ('12), who found in the bat a marked encroachment of the corpora lutea upon the stroma so that the outlines of the former are not clearly defined, but cords of interstitial cells become continuous with the corpus luteum. Such interstitial cells have the same aspect as lutein cells. There is some similarity between these two elements when the interstitial cells are maximal in the woodchuck. A typical lutein cell is shown in figure 29 and is seen, however, to be much larger than the largest interstitial cells; to be free from lipoids, which blacken with osmic acid; but to be literally filled with granules that resemble in almost every respect the larger fuchsinophile granules of the interstitial cells. In very early corpora lutea there are apparently lutein cells containing a few such fatty droplets but they soon disappear in the case of corpora lutea of pregnancy. Later towards the end of gestation and after parturition, such lipoid appears again, evidently as an expression of degeneration. In corpora latea resulting from rupture of follicles not followed by pregnancy, the lipoid appears much earlier. 
Two such corpora lutea are shown in figure $3\left(\mathrm{CL}^{\prime}\right)$ where the fatty content appears black.

Usually there is no difficulty in distinguishing corpora lutea from atretic follicles; but in one animal, containing very young foetuses, was found what was taken to be a corpus luteum much younger than the others and with considerable blood in the large central cavity. On following the series along it was found that it contained an ovum (indicated by $\mathrm{O}$ in figure 20). The theca interna had already been largely incorporated, as normally occurs in corpora lutea, so that it is not possible to exclude the cells of the theca interna from being the source of the large luteal-appearing cell, especially since what appears to be a few degenating granulosa cells are found about the egg and in the adjacent lutein tissue. The rest of the tissue cannot be distinguished from neighboring corpora lutea of pregnancy. However, only material fixed in Zenker's fluid and stained with iron hematoxylin, was available. In all probability this is another example of an abnormality where the granulosa cells have changed to lutein cells before the ovum has been discharged such as has been described in some other animals (c. f. Corner '15).

Capitvity and isolation during the spring.-Seven females which had hibernated in captivity and after waking had been with active males (which had also hibernated in captivity) for two to four weeks, were sacrificed between April 10 and April 24. None of these animals were pregnant. While the interstitial cells were more prominent than in animals killed just at the close of hibernation, the degree of hypertrophy just described was not found in a single case. Nearly all the interstitial cells, especially in animals that had been awake the longest, were very rich in lipoid and contained many mitrochondria, essentially as represented in figure $25 \mathrm{~b}$. They contained, however, very few of the large fuchsinophil granules.

The ovary in no case had enlarged much, if at all. Many atretic and some medium-sized normal follicles were present about as indicated in figure 8 . This figure shows the maximum interstitial cell development observed in animals kept in captivity. It is taken from another female which was kept till May 18 (three weeks longer than the seven animals above men- 
tioned) and which had been isolated from males since February 6 preceding. In this animal there had evidently been ovulation, judging from the young corpus luteum present. The other ovary showed two corpora lutea slightly older in appearance. Only two large ripe follicles were encountered in all these eight females kept in captivity during the spring.

Since in the woodchuck captivity does not interrupt the male sexual cycle (as far as the appearance of the testis is concerned, Rasmussen '17), it seems probable that the failure of these animals to breed in confinement is due to its effect on the female. This is suggested by the scarcity of large mature follicles in the ovary. However, M. Regaud, in discussing a paper by Branca ('03) on the testes of certain animals in captivity, reports (p. 198) that in the European marmot (belonging to the same genus as the woodchuck) no spermatogenesis occurs in males kept over winter-the testes in the spring remaining essentially as they are in winter during hibernation at which time the tubules hardly contain any cells of spermatogenic origin.

During pregnancy and lactation.-At the beginning of pregnancy the stroma is thus largely occupied by great masses of enlarged interstitial cells rich in lipoid and other granules. The growth of the corpora lutea together with the fact that frequently there is an unequal number of corpora lutea in the two ovaries, now become prominent factors in the weight of this organ, and are responsible for the unequal size frequently met with from now on till July or August. The ovary with the largest number of corpora lutea is always the heavier, one frequently being several times the weight of the other. The largest ovary obtained was one containing 5 corpora lutea and weighed $.285 \mathrm{~g}$. (.01163 per cent of net body weight) and was three times as heavy as the other ovary which contained only one corpus luteum. This was in the last of May, at least several weeks after parturition.

In the initial development of corpora lutea there is an inrush of the theca and neighboring stroma, carrying along with them many interstitial cells. In figure 9 the arrow indicates a group of interstitial cells (identifiable by their lipoid content, shown in black) thus being carried into a young corpus luteum in the direction indicated by the arrow. The fate of these cells 
cannot be stated. They soon lose the lipoid that blackens with osmic acid and either revert to connective tissue elements associated with the vascular framework of the corpus luteum, disappear entirely or become lutein cells. The source of the lutein cells and the fate of the inrushing theca cells, ete., is still a disputed question and one that cannot be entered into here. Corner ('15), who discusses at length the literature on the subject, believes it probable that in the sow some of the theca cells may remain in the fully formed corpus luteum as special cells distinguishable from the other lutein elements.

With the progress of pregnancy the interstitial cells in all parts of the ovary decrease in size but become relatively richer in lipoid at the expense of the larger fuchsinophile granules as seen in figure $27 \mathrm{a}$, which is a group of two cells undergoing atrophy and in which there are only five of these larger granules left in the particular section drawn. Practically all these coarse granules had disappeared in an animal containing foetuses $45 \mathrm{~mm}$. in length.

Mitochondria, as was also shown by Levi ('13) in a number of other animals, largely persist during this extreme fatty infiltration. The fatty globules of the regressive stages are slightly smaller and more closely packed than those present during the progressive stages and apparently produce a deformity of the nucleus. Occasionally, however, a number of individual droplets may fuse forming spherules even larger than the largest ones represented in figure 26. This lipoid is then gradually absorbed and as a consequence the cells diminish in size, as shown in figure 27 , till, in many cases at least, only fragmented and shriveled nuclei are left as in e of this figure. These picnotic nuclei apparently disappear quite rapidly. The interstitial cells left in the stroma between adjacent corpora lutea, are the first to disappear-probably on account of the pressure produced by these growing structures.

By the time of parturition many of the interstitial cells have disappeared entirely and the others are in various stages of decline. A general view of this condition is shown in figure 5. The interstitial cells remaining are in groups which appear intensely black because of the large amount of lipoid. In each dark area will be found side by side all the forms shown in figure 27. This process goes on during lactation. Figure 5 is 
from a lactating animal in which the uterus still was greatly congested giving evidence of recent parturition.

The figure indicates the large amount of atresia that has taken place. All the follicles large enough to show in the photograph, except one, are in advanced stages of degeneration, each appearing as an intensely black ring indicative of the heavy lipoid infiltration in the theca cells. Normal fully developed follicles may, however, persist for a considerable time after pregnancy has taken place. There were several such follicles in an animal with foetuses $40 \mathrm{~mm}$. to $45 \mathrm{~mm}$. in length.

The particular ovary from which figure 5 was taken contained only two corpora lutea and these were to one side of the median plane so that a section showing a good general view of the stroma nearly missed one corpus luteum and is not through the greatest diameter of the other. However, sufficient is included to show the lipoid which appears in the lutein cells at the expense of the secretion-like granules, as illustratèd in detail in figure 31 a.

In passing it may be noted that Van der Stricht ('12) in the bat and Corner ('15) in the pig regard the lipoid that appears in young lutein cells as secretion products. In the spermophile Drips ('17, '18) considers that the fatty droplets which appear in abundance comparatively late in pregnancy, during the decrease in the fuchsinophil granules, and which persist for about six weeks afterwards, as an internal secretion having to do with the normal involution of the uterus. In the woodchuck there seems to be no valid reason for considering the lipoid which appears in the corpus luteum during late pregnancy and immediately thereafter as being different from that which two months later completely fills these cells (fig. 6) and which evidently is an expression of degeneration. The uterus in the woodchuck appears to return to normal rapidly and long before there is very much lipoid in the lutein elements.

The gestation and lactation periods are apparently not known in the case of the woodchuck. The facts could not be determined because the animals would not breed in captivity: General observations show, however, that they become permanently awake during the second half of March (in the locality concerned) and most of them soon become pregnant for the 
majority of those caught in April contain foetuses. Lactating animals are obtainable in May and many young are seen in June.

In midsummer.-By July the interstitial cells have greatly diminished. In the last half of the month the medullary portion of the ovary is very poor in lipoid (fig. 6). There are, however, many cells nearly round in form and from 4 to 8 micra in diameter (nucleus from 3.8 to 6 micra), which rarely contain more than two or three lipoid granules and many that contain none. Such cells are fairly rich in mitochondria, considering the scanty cytoplasm. They may be represented by $b$ and $d$ of figure 24, d of figure 27 and figure 28 . In the cortical zone there are in addition a considerable number of cells with somewhat more lipoid and occasionally as large as $\mathbf{1 2}$ micra. There are also many cells entirely free from lipoid with more or less elongated nuclei as well as spherical which appear to have been newly derived from cells that have migrated down from the germinal epithelium as shown in figure 21 and as will be discussed under another heading. It is therefore difficult to say how many of the interstitial cells of this stage are survivals of the retrogression of the hypertrophied cells of earlier months and how many are new derivatives from either ordinary stroma cells or other cells which apparently have migrated into the stroma from the germinal epithelium and which migrate into the masses of atrophic interstitial cells and degenerating corpora lutea. The appearance of the center of the larger groups of retrograding cells into which no migratory cells appear to have penetrated, would indicate that many interstitial cells persist as lipoid free cells essentially like figure $24 \mathrm{~b}$. The nuclei of other stromal elements that transform into interstitial cells do not become round before more or less lipoid has made its appearance in the cytoplasm.

Now and then a cell, such as is shown in figure 28 , is encountered which almost certainly is derived from the larger lipoid-laden cells, as is evident from the presence of a large spherule which appears to be the remains (now probably pig. mentary in character and more resistant to absorption) of the granular content once so abundant. This is altogether probable for pigmentary degeneration of the hypertrophied interstitial 
cells, while not common such as it is in the testis of this species, does occasionally occur, and a few large pigment-laden cells are seen at this time of the year and later. Such cells have all the characteristies of the pigment cells of the testis which will be mentioned again a little later. They are easily picked out by copper hematoxylin, iron hematoxylin, acid fuchsin, crystal violet and Sudan III after chromation because of the lipochrome content.

The lutein cells have by this time become densely infiltrated with lipoid so that the corpora lutea, which may still be maximal in size, make exceedingly conspicuous structures in material fixed in osmic acid, as is illustrated in figure 6. Most of the lutein cells in such corpora lutea are like figure $31 \mathrm{~b}$, although all the cells are not in the same stage of retrogression. After this stage has been reached, the lutein cells rapidly lose their lipoid and finally disappear completely. Figure 31 shows several stages of this fatty infiltration and the subsequent atrophy.

In August, corpora lutea in various stages of atrophy are regularly seen. With the disappearance of the corpora lutea, the ovary diminishes greatly in size, falling down to about .0008 per cent of the body weight. A typical ovary just before the last traces of corpora lutea have been absorbed is shown in figure 7. The black area consists of atrophied lutein cells that have not yet disappeared. In such degenerating corpora lutea are found a few cells, such as are shown in figure $31 \mathrm{~d}$, resembling interstitial cells. Their source is not clear. They may have been derived from lutein elements as Van der Stricht ('12) suggests. This investigator asks the question if it might not be that such cells as appear not to degenerate completely in the bat are the original theca cells. It has also been mentioned that there is a migration of cells into such degenerating corpora lutea from the outside and this may be the source of the cells in question. Certainly the lutein cells practically all undergo complete atrophy and leave very little evidence, aside from an occasional pigment cell, of their former presence.

There is during this period and also earlier, during late gestation, renewed development of follicles. Primary follicles become very numerous and some of these are enlarging and 
sinking deeper into the ovary. Mann ('16) and Drips ('17) describe a similar development of follicles before the period of hibernation in the spermophile.

\section{Conclusions}

The observations seem to warrant the conclusion that there is an annual eycle going on in the ovary of the woodchuck in connection with interstitial cells. This consists of a very slow hypertrophy of some of the cells during late autumn and during hibernation, which is followed by a more rapid development, in which all the interstitial cells are involved, during the spring after waking up from winter-sleep. The maximum is reached at the time of ovulation and beginoing pregnancy and especially in those individuals that do not become pregnant till a month or so after the majority of the females conceive. Retrogression consisting of a decrease in size and number of cells, follows with the progress of pregnancy and by July, which is several weeks after lactation has ceased, they have reached a minimum. During retrogression there is renewed activity in the downgrowth of cells from the germinal epithelium which appears, as will now be discussed in further detail, to give rise to new elements that transform into interstitial cells which, in connection with those that have resulted from atrophy of the enlarged cells of the existing cycle, are ready to commence the next cycle.

\section{ORIGIN OF THE INTERSTITIAL CELLS OF THE OVARY}

The origin of the interstitial cells of the ovary has been much debated. His ('65), Tourneux ('79), Janosik ('85, '88), Child ('97), Plato ('97), Coert ('98), Rabl ('98), Regaud et Policard ('01), Limon ('02), Allen ('04), Saimont ('05), Aime ('07), Von Winiwarter ('08), Ciaccio ('10), Popoff ('11) (in the dog), Athias ('11), Van der Stricht ('12), Kingsbury ('14) and Firket ('14) all have derived them directly from the stroma cells, which are considered a type of connective tissue. O'Donoghue ('16) admits that in marsupials they may have arisen from the stroma cells at a very early stage. Janosik ('88), Schottländer ('91, '93), von Kölliker ('98), Rabl ('98), Clark ('98), Regaud et Policard ('01), Van der Stricht ('01, '12), Limon ('02), Cohn ('03, '09), Allen ('04), Saimont ('05), Seitz ('06), Aimé ('07), Wallart ('07), Regaud et Dubreuil ('07, '09), Benthin ('11), Popoff' ('11) (in weasel and mole), Aschner ('14) and Kingsbury ('14), that is, many of the authors already named and some others, consider that they also: come from the cells of the theca interna of atretic follicles. This 
would appear, after all, to be only an indirect derivation from the stroma cells and one that is prominent in later stages of development and in the adult. v.d.Broek ('10) insists that in marsupials they originate independent of either atretic follicles or corpora lutea. Against the connective tissue origin are the views of Nussbaum ('80), Schulin ('81), Horz. ('83), Paladino ('87), Lane-Claypon ('06), Ganfini ('07, '08) and M'llroy ('17), who believe they are epithelial in origin, being derived from the mesothelial covering of the ovary. Popoff ('11) believes there is a double origin in the mole where they appear to originate also directly from the epithelium as well as from the theca interna. Firket ('14) describes also a double origin in the chick where the interstitial cells appear to come both from the stroma and from the medullary cords. But since in the fowl ovary some of the elements that have been considered interstitial cells by many are now regarded by Pearl and Boring ('18) as lutein cells which appear in groups mostly in the theca interna, it is not clear how this will affect the conclusions of Firket.

A number of other sources that have been suggested, especially by older workers, are of historical interest only and need not be mentioned here.

It appears, therefore, that of the two sources of interstitial cells, the stromal origin, either direct or indirect through the theca interna of atretic follicles, is held by the vast majoritythe epithelial as the exclusive source or in addition to the stromal origin being supported by only a small minority.

A thorough-going investigation into the embryology has been carried out on so few animals that it is not surprising some disagreement should prevail and possibly there is some difference in animals of different species. Then too, the ordinas'y stroma cells of the ovary are not all typical connective tissue and if traced far enough back it is difficult to exclude them from having arisen from the coelomic mesothelium. There is some typical connective tissue, especially along the larger blood vessels and in the tunica albuginea. This in general has migrated into the ovary through the hilum. It appears altogether probable that many of the stroma cells may retain, even in the adult, many embryological characteristics so that they are capable of further differentiation such as occurs during ripening of follicles and atresia when the theca cells become quite different from the ordinary stroma cells, from which they are almost universally recognized as having been derived. If such hypertrophy can take place, there should be no serious difficulty in understanding, the derivation of interstitial cells from ordi- 
nary stroma cells not related to follicles. In mammals the hypertrophied cells of the theca interna, especially of atretic follicles, are regarded by the great majority of investigators as differing in no essential from other interstitial cells - a view also fully supported here upon the evidence presented by the woodchuck (fig. 22). Such a connective tissue (stromal) origin has, however, been urged as an argument against the theory that they are secretory in function.

This subject of the origin of the interstitial cells of the ovary, while in a sense quite separate from that of eyclic changes, was forced into the discussion because of the activity noted in the germinal epithelium in adult woodchucks especially during the rapid decline of the interstitial cells. Even during the latter part of dormancy the epithelium shows some degree of activity judging from a thickening seen here and there due to a prolifieration of cells so that a second layer forms beneath the superficial one, as is illustrated at point a in figure 21. Such activity increases with awakening when cells soon appear to be leaving the germinal epithelium, penetrating the tunica albuginea usually in a very oblique manner, as illustrated in figure 11. During pregnancy this migration is conspicuous. A general view from a pregnant animal (foetuses 40 to $45 \mathrm{~mm}$. in length, killed April 17) is shown in figure 11. A more detailed view of the superficial part of the same section is shown in figure 12. The cells of the germinal epithelium are seen to form a very irregular outline in places. The degree of differentiation of the stain (iron hematoxylin) has left the nucleus of the cells black while the outlines of the cytoplasm are indistinguishable. The ordinary connective tissue cells of the tunica albuginea are not visible. This contrast is possible because of the larger size and hyperchromatic character of the nuclei of the cells of the germinal epithelium and of those cells that appear to migrate from it.

These migratory cells are apparently somewhat amoeboid and in penetrating the tunica albuginea assume very irregular shapes as is recognizable in figure 13 and shown in more detail in figure $23(\mathrm{~d}, \mathrm{e}, \mathrm{f}, \mathrm{g}, \mathrm{h}, \mathrm{i})$. In most places the tunica albuginea remains intact, making it necessary for the cells to take a very oblique and devious course in order to get through as shown in figures 12 and 13. In a few limited areas, as shown in 
figure 14, the tunica albuginea becomes interrupted due, apparently, to the large number of cells passing through it. In such places the cells stretch in a continuous mass from the germinal epithelium to the cortical layer of follicles.

In penetrating into the ovary some of these cells surround and come in close association with both primary and secondary follicles as shown in figure 15 , where they may be recognized by the dark oblong nucleus. They are seen frequently to be in contact with the basement membrane of the granulosa and in all probability may become constituent parts of the theca interna. Deeper in the ovary they enter groups of interstitial cells and since there exist all the intermediate forms that one could wish, as illustrated in figure 19 , between them and typical lipoid-laden interstitial cells with vesicular nucleus, it appears that they are a source of interstitial cells.

Wherever these cells are encountered, some of them give the appearance at first sight of being in process of division. The rare occurence of any form of multiplication in the interstitial cells of adult animals, stimulated a more careful study of such apparently dividing cells. A variety of representative cells are shown in figure 23 ( $d, e, f, g, h, i)$. It seems that what appeared to be a typical chromosome arrangement in dividing cells as suggested in $\mathbf{f}$ and $\mathbf{g}$ of figure 23 , is really dne to folding of the cells, possibly because of the resistance offered by the stroma. Although there are many suggestions of amitotic cell division, 'such as is shown in figure $23 \mathrm{e}$, no unmistakable evidence that such actually occurs was seen. Direct cell division has however been described in the interstitial cells of the ovary. Some of the figures published by Regaud and Dubreuil ('06) as evidence of amitosis in young interstitial cells of the rabbit ovary simulate closely what has just been described here in the woodchuck.

One disappointing feature is the scarcity of valid proof of cell division in the germinal epithelium such as would be expected if the cells are rapidly increasing in number. Only occasionally is a mitotic figure seen (fig. $14 \mathrm{M}$ ). Such forms as are shown in $a$ and $b$ of figures 23 are numerous, but these are only sharply bent cells evidently due to lateral pressure in the epithelium. A possible factor entering here is the fact 
that nearly all ovaries after removal from the body were weighed on an ordinary chemical balance and unprotected from the drying influence of the air. As a consequence the small organ rapidly cooled and the germinal epithelium, except in protected places, was affected by drying. However, a few ovaries were dropped immediately into the fixer and still in these evidence of much cell division is wanting.

Later in the season, in July and August, when the corpora lutea are rapidly degenerating and the interstitial cells are greatly reduced, groups and columns of cells from the germinal epithelium penetrate the tunica albuginea in regions between corpora lutea and near the hilum, as is shown in figure 21. Some of these groups, consisting of one cell surrounded by a few slightly smaller ones, are suggestive of oögenesis. The formation of definitive ova in nearly mature animals by a differentiation of cells from the germinal epithelium, has been described by von Winiwarter and Sainmont ('08) in the cat and by Kingery ('17) in the white mouse, showing that the tunica albuginea is no barrier to a migration of groups of cells from the epithelium to the interior of the ovary, at least in some animals, and that oögenesis may take place long after it is generally supposed that such occurs, as far as participation of the germinal epithelium is concerned. In the woodehuck, however, there are not the necessary intermediate stages between such groups of cells as shown in figure $21 \mathrm{~b}$ and primary follicles to warrant the conclusion that any of these cells leaving the germinal epithelium in groups in adult woodchucks ever become oöcytes. It appears rather that they form cords that extend into the medulla or remain in the more superficial part of the ovary as irregular masses and cords of cells as illustrated in figure 21 in the region about the point marked C.

The nucleus of these cells when first formed tends to double on itself. Not rarely is a picture such as is represented in . figure $23 \mathrm{e}$ observed where every cell in a cross section of one of these cords has a curved or s-shaped nucleus.

The cell cords and especially those that extend into the medullary region become separated from the surrounding stroma by a well defined membrane. Such walled-off cells do 
not appear to change much the year around. At least during hypertrophy of the interstitial cells there are many unaltered medullary cords and no evidence that any have changed to interstitial cells. It appears quite different with the great bulk of the cells that remain in the cortical zone and do not become organized into definite cords. Transitional forms between these and typical interstitial cells are seen in these, especially during spring hypertrophy, but even late in summer and in autumn many of them acquire a few lipold granules and appear in every way to become interstitial cells which must in a large measure take the place of those that disappear annually.

Downgrowth of the epithelial covering of the ovary of adult animals has been described in a number of animals. Paladino ('87, '88) noted that in the adult pig, horse, cow, sheep, goat, guinea pig and woman, the tunica albuginea does not prevent epithelial invaginations from occurring. $\mathrm{He}$ believed that such downgrowths replace degenerated structures and found that in old age the process tends to be limited to the region near the hilum, although it may take place anywhere. Regaud and Policard ('01) show tubular or columnar masses of cells entering the ovary from the epithelium of adult dogs, and emphasize the secretory character of the constitutent cells, having demonstrated what they consider to be secretion granules. The hyperchromatic character of the nucleus of some of the cells is also considered by these investigators to be related to secretory activity. Such diverticula are not present in all species. There are frequently crevices and fairly. deep depressions in the ovary; but these do not penetrate the tunica albuginea and are not to be confused with the downgrowth described above.

While it is thus believed that the germinal epithelium contributes to the formation of interstitial cells of the ovary of the adult woodchuck, it is also equally certain that the ordinary stroma cells appear to hypertrophy and become interstitial. cells. During rapid development of the interstitial cells, long spindle-shaped stroma cells are seen which are much richer in mitochondria than usual (fig. 30, a). Others are found with a larger, more nearly round and less granular nucleus and still 
more mitochondria and usually a few lipoid droplets as figure 24 , a, and figure $30, \mathrm{~b}$. There are also abundant forms all the way to typical interstitial cells (fig. 19).

The indications are, therefore, that the interstitial cells which disappear annually are replaced by cells from the germinal epithelium as well as from the stroma directly and also indirectly through the theca interna. Nothing can be said here about the origin of the stroma since no embryological work has been done on this species.

\section{RESTUDY OF THE INTERSTITIAL CELLS OF THE TESTIS}

\section{THE PRESENCE AND BEHAVIOR OF MITOCHONDRIA}

In the recent report on seasonal changes in the interstitial cells of the testis of the woodchuck already referred to, it was shown that the ordinary interstitial cells, containing only a slight amount of pigment and oceasionally none at all and shown in figure $32, \mathrm{a}, \mathrm{b}, \mathrm{c}$, are minimal in late summer and autumn and remain so during hibernation. With awakening in the spring there follows an increase in the size (fig. 33, a) and number, finally becoming many times their former size (fig. 34 , a) and remaining hypertrophied till midsummer when most of them decrease (fig. 35, a) and soon return to their original minimal size (fig. 36, a, b, c). A number, however, were described as not decreasing materially in size but as undergoing a form of pigmentary degeneration, resulting in the formation of cells literally filled with a yellowish lipochrome in the form of granules of various sizes (fig. $36, p$ ) and which are very resistant to fat solvents. These pigment cells are fairly conspicuous in autumn and during hibernation (fig. $32, p$ ); -but decreases in size and in number more rapidly during the spring (fig. $33, \mathrm{p}$ and fig. $34, p)$ and almost or entirely disappear during general interstitial cell hypertrophy.

It was further stated that with the technique employed all attempts to bring out mitochondria in the two types of interstitial cells of the testis, failed and that this point would need further investigation. Whitehead ('12) finally described in the interstitial cells of the pig testis what must evidently be re- 
garded as mitochondria. Van Winiwarter ('12) has demonstrated their presence in the form of granules and filaments in all the interstitial cells of the human testis, but in less quantity where other cytoplasmic inclusions are more numerous. In the opossum they were observed by Jordan ('11) and have recently been described by Duesberg ('18) as being exceedingly numerous, mostly rods, short and curved, and crowded into several heaps. Since these structures are so generally present in other living cells, it seemed improbable that they should be absent in the interstitial cells of the woodchuck testis.

Having had no difficulty in demonstrating mitochondria in the homologous cells of the ovary and in other tissues of the woodehuck especially with acid fuchsin and methyl green after either neutral formalin-bichromate or acetic-osmic-chromic fixation, 14 additional animals were injected with neutral formalin and potassium bichromate as advocated by Cowdry ('16b). This new material and that part of the tissue from the former study which was well fixed in the acetic-osmic-chromic mixture were investigated principally by staining with acid fuchsin and methyl green. The results are shown in figures $32,33,34,35$, and 36 , in which the mitochondria appear as small red granules. Nearly all these granules are round. A few are slightly elongated, but they are never filimentous.

The pigment, normally yellow in color, may remain unstained or stained only on the surface, as shown in the four large composite granules of figure $32, \mathrm{p}$. When stained they may take the acid fuchsin or this stain may be replaced by methyl green, depending upon the amount of dichromatization and the length of time the respective stains are allowed to act. In well fixed material it is possible to gauge these factors so that all fuchsin will be driven from the pigment by the methyl green and leave only the mitochondria red as shown in figure 32 , c. Intermediate colorizations are, however, frequently obtained in which the pigment has been stained only on the surface of the granule so that the yellow becomes modified either towards the red or the green. These different effects may be obtained on the pigment within a single cell as is shown in figure $32, \mathrm{p}$ and $\mathrm{b}$. But where some of the pigment has taken the red stain, it is usually possible readily to distinguish it from mitochondria, 
which are much smaller than even the smallest pigment granule. Then too there are a few very small interstitial cells, frequently irregular or slightly elongated in form, which contain no pigment to complicate the picture. In these the mitochondria are exactly the same as those found in the cells that do contain pigment. The mitochondria of the interstitial cells show best in preparations that also exhibit most clearly the mitochondrial content of the neighboring spermatogenic tissue. So it is believed that there is no question about the presence of mitochondria in the interstitial cells both of the ordinary and of the heavily pigmented type.

The suggestions given by Cowdry ('16b) on the causes of failure and the remedy were of great value in discovering the proper time intervals for each block of tissue. An evident source of trouble in earlier attempts to utilize acid fuchsin and methyl green was the excess of fixer left in the tissue by the very rapid washing and dehydration employed. It was necessary to leave some of the acetic-osmic-chromic fixed material for ten minutes in the potassium permanganate. The necessity of apparently excessive fixation was not fully realized, as is apt to be the case with the uninitiated:

As the ordinary interstitial cells enlarge in spring, the mitochondria increase in number simultaneously with the appearance of the large lipoid granules, as shown in figure 33 , a, where the lipoid which blackens with osmic acid appears as vacuoles. Many of the mitochondria also appear to become larger. They are most numerous in the perinuclear cytoplasm, but appear through the cytoplasm between the fatty globules and dispersed pigment, the latter being shown in blue in figure 33. As the cells continue to enlarge there appear in the central cytoplasm granules, which are distinctly larger than the mitochondria and many intermediate in size, all of which stain like mitochondria and hence make it difficult to say which are mitochondria and which are not (fig. 34, a). It appears to be a less perfect preservation and staining of these large granules which were described in the first report, where granules of a lipoidal character were shown to be associated with the dense central cytoplasm. 
From the presence of intermediate granules and in view of the many accounts of the transformation of mitochondria into secretion granules and various metaplasmic products (cf. Cowdry ' 16 a), it could easily be believed that the larger fuchsinophil granules have developed from mitochondria; but such a transformation has not been proved in this case. These large fushșinophil granules are more easily preserved and show in preparations not sufficiently well fixed to demonstrate mitochondria. In well fixed tissue, however, all attempts failed to distinguish by color reaction the two types of granules, although the technique permits of considerable selective staining by varying the amount of dechromatization and stain differentiation. In the pancreatic cells, for example, the long filamentous mitochondria situated in the basal part of the cells may be left red while the round zymogen granules nearer the lumen are bluish green.

As shown in figure 34 a, a few of the large fuchsinophil granules may be found at the very periphery of the cell, but nearly all are confined to the central cytoplasm.

In midsummer, usually in July when the enlarged cells are undergoing atrophy (fig. 35), there is an absorption of all of the large fatty globules which occupy mostly the peripheral cytoplasm. In most of the cells many of the large fuchsinophil granules also disappear (fig. 35, a). When atrophy is complete, as is shown in figure 36 , none of the typical large fuchsinophil granules are left, though a considerable number of mitochondria persist.

The mitochondria, which are scattered throughout the cytoplasm of the pigment cells, decrease with the gradual disappearance of these cells ; but as long as pigment cells are recognizable, mitochondria are demonstrable within them ( $p$ of figures $36,32,33$ and 34 ).

\section{THE SOURCE OF THE PIGMENT GRANULES}

During the midsummer involution of the interstitial tissue, when most of the fuchsinophile granules disappear from many of the cells, there occurs a marked increase in pigmentation of the testis. This is evidently due to a transformation of the fuchsinophil granules that are not absorbed, into a pigment, 
which is easily differentiated from mitochondria. In figure 35 , a, all of these large fuchsinophile granules except three have been so changed that they can be made to take the methyl green while the mitochondria remain red. The three large red granules have not yet become sufficiently changed to be thus distinguished. When the final stage of atrophy is reached some pigment remains in all but a very few of the smallest cells (fig. 36, a, b and c.) This pigment largely persists till hypertrophy commences again in the following spring when it decreases markedly, becomes dispersed in the abundant newly acquired cytoplasm (fig. 33, a), and in most cases disappears entirely.

In the formation of the large pigment cells it appears that the fatty globules which blacken with osmic acid (shown as vacuoles in fig. 34, a) are absorbed as usual and are not transformed bodily into lipochrome as was rather suggested in the earlier report. Simultaneously with this absorption there is a marked increase in the large fuchsinophile granules. In figure $35, b$, where is illustrated a transformation stage, the large amount of these fuchsinophil granules is shown just before the last trace of lipoid is gone. To the right of the nucleus are three bluish-green granules. These are pigment. All the fuchsinophil granules finally appear to undergo pigmentation and the result is a cell like $\mathrm{p}$ in figure 36, where the pigmentation is shown either in yellow or bluish-green. This particular cell is somewhat larger than usual, showing the size they may attain,

It further appears that the large pigment granules are aggregations of the smaller ones. This is seen in figure $32, p$, but is especially evident just after these cells are formed (fig. $36, \mathrm{p}$ ). This coalescence becomes more intimate with time so that the individual droplets involved are not seen as is indicated in figures $33, \mathrm{p}$ and $34, \mathrm{p}$.

\section{COMPARISON OF THE INTERSTITIAL CELLS OF THE TESTIS AND THE OVARY}

The foregoing account in connection with the former report on seasonal changes in the testis shows that the interstitial cell eycle, not only in time but also in many cytological details, is somewhat similar in the male and the female woodchick. 
This is easily seen by comparing the right hand row of figures in plate 4 with the parallel arranged left hand row of figures in the same plate. In both cases there is a rapid hypertrophy in the spring after hibernation; but in the ovary this has been preceded by a gradual increase which has been going on during hibernation and sometimes longer; while in the testis there is practically no change till after dormancy. Involution of this tissue is also more gradual in the ovary, where in the case of pregnancy it is going on during April, while in the testis the interstitial cells continue maximal till June or July. The minimal stage is, however reached at about the same time, that is by August. In both cases there is no sudden change with the onset of hibernation, an observation also made by Mann ('16) on the spermophile.

It is, of course, impossible to say with certainty exactly how long the interstitial cells remain hypertrophied in a given individual because tissue cannot be removed from the same animal at various intervals through the year and still leave the animal normal and because the animals involved were captured promiscuously in the field and hence have not a known history. The above comparisons are deduced from the conditions generally prevailing among animals sacrificed at certain periods of the year and showing collateral evidences of being at a given stage in the sexual cycle.

One would be tempted to suggest that the longer hypertrophic stage of the interstitial cells of the testis is related to a longer period of sexual activity in the male. This, however, is not warranted by the presence of ripe spermatozoa for a sufficiently long time nor by the general habits of this species, since they are said to live together in pairs.

During hypertrophy of the interstitial cells of both ovary and testis, the number of mitochondria increase and there appear larger fuchsinophil granules and still larger fatty globules in the cytoplasm. There is considerable individual variation in the relative number of fuchsinophil granules and the larger lipoid bodies-the two constitutents being inversely proportional to each other in both the ovary and the testis.

During atrophy of the interstitial cells of the ovary, the large fuchsinophil granules disappear first leaving large cells 
that contain only mitochondria and the large fatty globules which are next absorbed. In the testis the fatty matter and large fuchsinophil, granules either disappear more or less together or the former is lost first.

In nearly all the interstitial cells of the testis some of the large fuchsinophil granules, and in a smaller number of them apparently all of these granules, become pigment which remains for months to nearly a year. Such pigmentation rarely oceurs in the interstitial cells of the ovary.

While most of the interstitial cells of the adult ovary are rarely or only for a short time entirely free from lipoids that blacken with osmic acid, those of the adult testis practically contain such fatty matter only after spring awakening and until July or August.

In the mole a somewhat similar correspondence exists between the duration of hypertrophy of the interstitial cells of the testis and of the ovary, but in both cases the time of hypertrophy does not coincide with the breeding period of early spring and the maximum enlargement of the interstitial cells of the ovary comes somewhat later in the year than in the case of the interstitial cells of the testis. Sufficiently complete descriptions are not given of other animals to make any further comparisons.

As to whether the interstitial cell hypertrophy in either the testis or the ovary is a cause or an effect is debatable. While the presence of the fatty globules and other granules has been taken as evidence of secretory activity, such a conclusion does not necessarily follow. One would expect that if such were the case, the changes in such content would more closely correspond to some particular phase of the sexual cycle than they do, especially in the testis. The interstitial cell activity of the ovary is fairly closely related to ovulation and beginning preg. nancy, except in the mole. It would seem, however, very desirable to have the mole as well as many additional species further investigated before drawing conclusions.

An important alternative to the secretory theory of the interstitial cells, is the view that the periodic increase is merely an expression of hyperemia and the general changed metabolism accompanying ovulation and pregnancy. It seems diff. 
cult to prove that such is not the case. And, as emphasized by Kingsbury ('14), it is equally hard to exclude the probability that the interstitial cell hypertrophy is related to degenerative changes in the gonads. This is especially true of the theca cells of atretic follieles. Why the interstitial cells not related to follicles are involved is not so well harmonized. Many pathological findings, especially in hermaphrodites, are further difficulties in the way of a satisfactory explanation. In short, the secretory function of the interstitial cells of both the testis and the ovary, while in general assumed, is full of uncertainties. A good statement of the present status of the internal secretary activity of the testis has recently been made by Wheelon ('17).

Neither spermatogenesis nor follicular development are interrupted or modified during atrophy of the interstitial cells, indicating that at least some phases of the primary function of the gonads are independent of interstitial cell activity.

\section{SUMMARY}

1. The literature on cyclic changes in the interstitual cells of the ovary is reviewed and indicates in general a hypertrophy of these elements during rut and pregnancy.

2. A marked annual periodicity in the interstitial cells of the ovary of the woodchuck (Marmota monax) is described as consisting of a gradual enlargement during winter followed by a more rapid hypertrophy after hibernation. The cells become three to four times their original diameter. Maximal increase is seen in females that have not become pregnant until late in the breeding season.

3. The increase in the size of the cells is due to an accumulation of lipoid and secretion-like granules in the cytoplasm, though the nucleus also increases. Mitochondria similarly increases in number and some, possibly, in size.

4. Retrogression sets in with the onset of pregnancy and the growth of corpora lutea and continues until July.

5. In the decline the lipoid and large fuchsinophil granules and finally the entire cell disappear in many cases. The cells that survive atrophy retain a number of mitochondria, but the other granules are absorbed.

6. Pigmentary degeneration is rarely observed. 
7. The interstitial cells of the ovary are minimal in size during late summer and early autumn, but tend soon to acquire lipoid and slowly to enlarge.

8. During late involution of the interstitial cells the follicles show a tendency to grow. By autumn a number of fairly large Graafian follicles and many smaller ones are evident.

9. The origin of the interstitial cells of the ovary is briefly discussed and shown to be regarded by the vast majority as having come from connective tissue, or stroma of the ovary, either directly or indirectly through the theca interna of atretic follicles. A few investigators insist on an epithelial origin.

10. Proliferation of the germinal epithelium in adult ovaries indicates strongly a formation of new interstitial cells from elements that migrate into the ovary from its covering epithelium. This is most noticeable from late in pregnancy till late summer.

11. Transformation of stroma cells into interstitial cells in adult animals is also evident. There appears to be no difference between the hypertrophied cells of the theca interna of atretic follicles and interstitial cells that are not related to follicles.

12. The persistence of full-sized corpora lutea of pregnancy until many weeks after parturition and the appearance of an abundance of fatty globules in the lutein cells before they decrease in size was observed. All corpora lutea have disappeared by September.

13. A restudy of the interstitial cells of the testis of the woodchuck is included. The presence of mitochondria in the form of round granules in all types of interstitial cells is reported. These mitochondria increase in number and some also in size during hypertrophy.

14. A better demonstration of the small lipoid granules of the central cytoplasm shows that they have many of the staining reactions of mitochondria but are distinctly larger in size.

15. These small granules and not the larger and more peripherally placed fatty globules are believed to be the source 
of the lipochrome, or pigment, which is formed during atrophy of the interstitial cells of the testis.

16. The large pigment granules are formed by the coalescence of smaller ones.

17. The general similarity in the interstitial cells of the testis and of the ovary is shown. The main differences between them are the more sudden hypertrophy and subsequent atrophy that occur in those of the testis and the almost entire absence of pigmentary degeneration in those of the ovary.

My thanks are due to Dr. B. F. Kingsbury of Cornell University for suggesting the problem and for counsel during the prosecution of the work; and to Dr. Sutherland Simpson of the department of Physiology for generous aid in procuring material. I take this opportunity also of thanking Dr. C. M. Jackson for the privilege of carrying out the major part of the histological work at the Institute of Anatomy in the University of Minnesota.

\section{LITERATURE CITED}

Aimé, P. 1907 Recherches sur les cellules interstitielles de l'ovaire chez quelques mammifères. Thèse. Nancy. Arch. de Zool. expér. et génér., Série 4, T. 7, p. 95.

Allen, B. IM. 1904 The embryonic development of the ovary and testis of the mammals. Am. Jour. Anat. vol. 3, p. 89.

Anzilotti 1909 Contributo sperimentale allo studio della cosidetta glandula interstiziale dell'ovaio. Ann. di Ostet. e Ginec. (Cited by Pardi '14a.)

Aschner, B. 1914 Über Morphologie und Funktion des Ovariums unter normalen und pathologischen Verhältnissen. Arch. f. Gynaek., Bd. 102, p. 446.

Athias, M. 1911 Observations cytologiques sur l'ovaire des mammifères. I. Les cellules interstitielles de l'ovaire chez le cobaye (foetus à terme et nouveau-né). Anat. Anz., Bd. 39, p. 238.

1912 L'appareil mitochondrial des cellules interstitielles de l'ovaire du murin. Compt. Rend. Soc. de Biol., T. 73, p. 448.

1916 Sur le déterminisme de l'hyperplasie de la glande mammaire et de la sécrétion lactée. Compt. Rend. Soc. de Biol., T. 79, p. 557.

Balfour, F. M. 1878 On the structure and development of the vertebrate ovary. Quart. Jour. Micr. Sc., N. S., vol. 18, p. 383.

Basso, G. $\bar{L} .1906$ Modificazioni istologiche delle ovaie in gravidanza con speciale riguardo alla theca interna dei 
follicoli atresici. Raccolta di scritti pel Giubileo didottico del prof. Mangiagalli.

Bayer, II. 1908 Anatomie der weiblichen Geschlechtsorgane. Vorlesungen über Allgemeine Geburtshülfe. Bd. 1, Heft 3, p. 259 . (cf. p. 500.)

Bell, W. Blair 1916 The Sex Complex. London, 1916.

Benthin, W. 1911 Über Follikelatresie in Säugetierovarien. Arch. f. Gynaek., Bd. 94, p. 599.

Bianchi, D. C. 1907a - Osservázioni sulla struttura a sulla funzione della cosidetta ' ghiandola interstiziale del' ovaia." Arch. di Fisiol., vol. 4, p. 523.

1907b Osservazioni sull'modo di compostarsa della ghiandola interstitiale dell'ovaio negli animali ibernanti. Boll. de Soc. med.-chir. di Pavia, p. 222.

Biedl, A. 1913 Innere Sekretion, 2 Auflage, II. Teil, pp. 313 339.

Boring, A. M., and Pearl, R. 1917 Sex studies. IX. Interstitial cells in the reproductive organs of the chicken. Anat. Rec., vol. 13, p. 253.

Böshagen, A. 1904 Über die verschiedenen Formen der Rückbildungsprodukte der Eierstocksfollikel und ihre Beziehungen zu den Gefässveränderungen des Ovariums. Zeitschr. d. Geburtsh. u. Gynaek., Bd. 53, p. 323.

Bouin, M. 1900 Histogenèse de la glande génitale femelle chez Rana temporaria. Arch. d. Biol., T. 17, p. 201. (Thèse de la Fac. des Sc. de Nancy, 1900.)

Bouin, P., et Ancel, P. 1903 Recherches sur les cellules interstitielles du testicule des mammifères. Arch. d. Zool. expér., Ser. 4, T. 1, p. 437.

1909 Sur les homologies et la signification des glandes à sécretion interne de l'ovaire. Compt. Rend. Soc. de Biol., T. 67 , p. 464, 497.

Branca, A. 1903. Le testicule chez certains animaux en captivité. Compt. Rend. Assoc. Anat., session 5, p. 193.

v. d. Broek, A. J. P. 1910 Entwicklung und Bau des Urogenital-Apparates der Beutler und dessen Verhältniss zu diesen Organen andrer Säuger und niedern Wirbeltiere. Morph. Jahrb., Bd. 41, p. 437.

Cattaneo (cited by Pardi '14b).

Child, C. M. 1897 Centrosome and sphere in cells of the ovarian stroma of mammals. Zool. Bull. (now the Biol. Bull.), vol. 1, p. 87. (A shorter account is found in Seience, N. S., 1897, vol. 5, p. 231.)

Ciaccio, C. 1910 Contributo alla distribuzione ed alla fisiopatologia cellulare dei lipoidi. Arch. f. Zellforsch., Bd. 5, p. 235. 
Ciulla 1909 Lo ghiandole á secrezione interna in gravidanza. Palermo. (Cited by Pardi '14b.)

Clark, J. G. 1898 Ursprung, Wachstum und Ende des Corpus luteum nach Beobachtungen am Ovarium des Schweines und des Menschen. Areh. f. Anat. u. Physiol., Anat. Abt., p. 95.

Coert, H. J. 1898 Over de Ontwikkeling en den Bouw van de Geschlachtsklier bij de Zoogdieren meer in het bejzonder van den Eierstok. Inaug. Diss., Leiden.

Cohn, F. 1903 Zur Histologie und Histogenese des Corpus luteum und des interstitiales Ovarialgewebes. Arch. f. mikr. Anat., Bd. 62, p. 745.

1909 Über das Corpus luteum und den atretischen Follikel des Menschen und deren cystische Derivate. Arch. f. Gynaek., Bd. 87, p. 367.

Corner, G. W. 1915 Corpus luteum of pregnaney as it is in swine. Contributions to Embryology, vol. 2 (Publication No. 222, Carnegie Institution, Washington), No. 5, p. 71 .

Cowdry, E. V. 1916a The general functional significance of mitochondria. Am. Jour. Anat., vol. 19, p. 423.

— 1916b The structure of chromophile cells of the nervous system. Contributions to Embryology, vol. 4 (Publication No. 224, Carnegie Institution, Washington), No. 11, p. 29.

Cushing, H., and Goetsch, E. 1915 Hibernation and the pituitary body. Jour. Exper. Med., vol. 22, p. 25.

Drips, Della G. 1917 Studies on the ovary of the spermophile; with special reference to the corpus luteum. Thesis, University of Minnesota. Jour. of Morph. (in press).

- 1918 Studies on the ovary of the spermophile with special reference to the corpus luteum. Anat. Rec., vol. 14, p. 34 .

Dubreuil, G. 1911. Les mitochondries des cellules adipeuses. Compt. Rend. Soc. de Biol., T. 70, p. 48 ; Transformation directe des mitochondries et des chondriocontes en graisse dans les cellules adipeuses. Ibid., p. 264.

Duesberg, J. 1918. On the interstitial cells of the testicle in Didelphys. Biol, Bull., vol. 35, p. 175.

Falta, W. 1916 The Ductless Glandular Diseases. Translated and Edited by M. K. Meyer, 2nd Ed., p. 370.

Fellner, O. 1909 Zur Histologie des Ovariums in der Schwangerschaft. Arch. f. mikr. Anat., Bd. 73, p. 288.

Firket, J. 1914 Recherches sur l'organogenèse des glandes sexuelles chez les oiseaux. Areh. d. Biol., T. 29, p. 201. 
Foster, L. 1917 The Ovaries and Mental Disease. Proc. Roy. Soc. Med., vol. 10, Section of Psychiatry, p. 65.

Fraenkel, L. 1905 Vergleichende histologische Untersuchungen über Vorkommen drüsiger Formationen im interstitiellen Eierstocksgewebe (glande interstitielle de l'ovaire). Arch. f. Gynaek., Bd. 75, p. 443.

1911 Die interstitielle Eierstocksdrüse. Berl. klin. Wochenschr. (48 Jahrg., 1 Halbj.), p. 60.

Ganfini, C. 1907 Sul probabile significato fisiologico dell'atresia follicolare nell'ovaio di alcuni mammiferi. Arch. Ital. di Anat. et Embriol., vol. 6, p. 346.

1908 Sulla struttura e sviluppo delle cellule interstiziali dell'ovajo. Arch. Ital. di Anat. et Embriol., vol. 7, p. 373.

Gley, E. 1917 The Internal Secretions : Their Physiology and Application to Pathology. Trans. by Maurice Fishberg. Paul B. Hoeber, New York.

Greggio, E. 1910 Intorno alle modificazioni strutturali dell' ovaio in alcuni processi morbosi ed in alcune particolari condizioni fisiologiche. Arch. Ital. di Ginec., vol.. 13, p. 1.

Harz, W. 1883 Beiträge zur Histologie des Oyariums der Säugethiere. Arch. f. mikr. Anat., Bd. 22, p. 374.

His, W. 1865 Beobachtungen über den Bau des Säugetiereierstocks. Arch. f. mikr. Anat., Bd. 1, p. 151.

Janosik, J. 1885 Histologisch-embryologische Untersuchungen über des Urogenitalsystem. Sitzungsber. d. Kais. Akad. d. Wiss., Wien, Math.-Naturw. Kl., Abt. 3, p. 97. 1888 Zur Histologie des Ovariums. Sitzungsber. der Kais. Akad. d. Wiss., Wien, Bd. 96, p. 172.

Jordan, H. E. 1911. The spermatogenesis of the opossum (Didelphys virginiana) with special reference to the accessory chromosome and the chondriosomes. Arch. $f$. Zellforsch., Bd. 7, p. 41.

Keller, R. 1913 Ueber Veränderungen am Follikelapparat des Ovariums während der Schwangerschaft. Beitr. z. Geburtsh. u. Gynaek. Leipzig. Bd. 19, p. 13.

Kingery, H. M. 1917 Oogenesis in the white mouse. Jour. of Morph., vol. 30, p. 261.

Kingsbury, B. F. 1914 The interstitial cells of the mammalian ovary: Felis domestica. Am. Jour. Anat., vol. 16, p. 59.

von Kölliker, A. 1898 Über Corpora lutea atretica bei Säugetieren. Verh. d. Anat. Gesell. zu Jena. Ergänzungsh. zu Bd. 14, Anat. Anz., p. 149. 
Lane-Clapon, J. E. 1906 On the origin and life history of the interstitial cells of the ovary in the rabbit. Proc. Roy. Soc. London, Series B, vol. 77, p. 32.

Levi, G. 1913 Note citologiche sulle cellule somatiche dell' ovaio dei mammiferi. Arch. f. Zellforsch., Bd. 11, p. 516; Arch. Ital. de Biol., 1914, T. 61, p. 129.

Leydig, F. 1857 Lehrbuch der Histologie des Menschen und der Thiere. Hamm, G. Grote'sche Buchhandlung, p. 507.

Limon, M. A. 1902 .Étude histologique et histogénique de la glande interstitielle de l'ovaire. Arch. d'Anat. micr., T. 5, p. 155.

Loeb, L. 1911 Untersuchnngén über die Ovulation nebst einigen Bemerkungen über de Bedeutung der sogenannten "interstitiellen Drüse" des Ovariums. Zentralbl. f. Physiol., Bd. 25, p. 336.

1914 The correlation between the cyclic ehanges in the uterus and ovaries in the guinea pig. Biol. Bull,, vol. 27, p. 1.

- 1917 The relation of the ovary to the uterus and mammary gland from the experimental aspect. Surg., Gynec. and Obst., vol. 25, p. 300 .

- 1918 The relations between the interstitial gland of the testiele, seminiferous tubules and the secondary sexual characters. Biol. Bull., vol. 34, p. 33.

M'Ilroy, Louise 1917 Physiology of the female reproductive organs. New System of Gynecology, edited by Eden and Lockyer, London, vol. 1, p. 39.

MacLeod, M. J. 1880 Contribution a l'étude de la structure de l'ovaire des mammifères. Arch. d. Biol., T. 1, p. 241.

Mann, F. C. 1916 The duetless glands and hibernation. Am. Jour. Physiol., vol. 41, p. 173.

Meyer, R. 1913 Ueber die Beziehung der Eizelle und des befruchteten Eies zum Follikel-apparat, sowie des Corpus luteum zur Menstruation. Arch. f. Gynaek., Bd. 100, p. 1.

Montuoro, F. 1903 Sulle cellule midollari dell'ovaio del coniglio. Con tavola IV. Arch. Ital. d. Anat. ed. Embr., vol. 2 , p. 45 .

Mulon, P. 1910 Sur une sécrétion lipoide nouvelle de la glande interstitielle ovarienne. Compt. Rend. Soc. Biol., T. 69, p. 423.

Nussbaium, M. 1880 Zur Differenzierung des Geschlechts in Thierreich. Arch. f. mikr. Anat., Bd. 18, p. 1.

O'Donoghue, C. H. 1916 On the corpora lutea and interstitial tissue of the ovary in the Marsupialia. Quart. Jour. Micr. Sei., vol. 61, p. 433. 
Paladino, G. 1887 Ulteriori ricerche sulla distruzione e rinnovamento continuo del parenchima ovarico nei mammiferi. Napoli. (230 pp., 9 pl.).

- $1888 \mathrm{La}$ destruction et le renouvellement continuel du parenchyme ovarique des mammifères. Arch. Ital. de Biol., T. 9, p. 176.

Pardi, U. 1914a Sur la fonction endocrine de l'ovaire durant la gestation. Lo Sperimentale, p. 183; Arch. Ital. d. Biol., T. 61, p. 177.

— 1914b Sur les cellules interstitielles ovariques de la lapine et sur les éléments de la thèque interne de l'ovaire humain hors de la gestation et durant celle-ci. Lo Sperimentale, p. 409 ; Arch. Ital. d. Biol., T. 62, p. 353.

Pearl, R., and Boring, A. M., 1918 Sex studies. X. The corpus luteum in the ovary of the domestic fowl. Am. Jour. Anat., vol. 23, p. 1.

Pinto, C. 1905 Note istologiche sulle modificazioni delle ovaia in gravidanza. Ann. di Ostet. e Ginec., vol. 27, p. 476 ; Boll. d. Soc. med.-chir. di Pavia, p. 146.

Plato, J. 1897 Zur Kenntniss der Anatomie und. Physiologie der Geschlechtsorgane. Arch. f. mikr. Anat., Bd. 50, p. 640 .

Popoff, N. 1911 Le tissue interstitiel et les corps jaunes de l'ovaire. Arch. de Biol., T. 26, p. 483.

Pottet, M. 1910 Contribution à l'étude du corps jaune pendant la grossesse. Thèse, Paris.

Rabl, H. 1898 Beitrag zur Histologie des Eierstocks des Menschen und der Säugetiere nebst Bemerkungen über die Bildung von Hyalin und Pigment. Anat. Hefte, Bd. 11, p. 109.

Rasmussen, A. T. 1915 The oxygen and carbon dioxide content of the blood during hibernation in the woodehuck (Marmota monax). Am. Jour. Physiol., vol. 39, p. 20.

- 1917 Seasonal changes in the interstitial cells of the testis in the woodchuck (Marmota monax). Am. Jour. Anat., vol. 22, p. 475.

Regaud, C. et Dubreuil G. 1906 Richerches sur les cellules interstitielles de l'ovaire chez le lapin. Bibliogr. Anat., T. 15, p. 169.

1907 Variations macroscopiques de la glande interstitielle de l'ovaire chez la lapine. Compt. Rend. Soc. Biol., Paris, T. 63, p. 780.

1908 Parallélisme des variations macroseopiques et microscopiques de la glande interstitielle dans l'ovaire de la lapine. Compt. Rend. Soc. Biol., T. 64, p. 901. 
1909 Nouvelles recherches sur les modifications de la glande interstitielle de l'ovaire consécutives á l'isolement et à la cohabitation avec le mâle. Compt. Rend. Soc. Biol., Paris, T. 67, p. 348. (An analysis of the work of Regaud and Dubreuil has been made by Pottet in Ann. d. Gynécol. et D'Obstét., 1910, Série 2, T. 7, p. 363.)

Regaud, C. et Policard A. 1901 Notes histologiques sur l'ovaire des mammifèeres. Compt. Rend. Assoc. des Anat., Session 3, Lyon, p. 45.

Saimont, G. 1905 Recherches relatives à l'organogenèse du testicule et de l'ovaire chez le chat. Arch. de Biol., T. 22 , p. 71.

Schaffer, A. 1911 Vergleichende histologische Untersuchungen über die interstitielle Eierstochsdrüse. Arch. f. Gynaek., Bd. 74, p. 491.

Schottländer, J. 1891 Beiträge zur Kenntniss der Follikelatresie nebst einigen Bemerkungen über die unveränderten Follikel in den Eierstocken der Säugetiere. Arch. f. mikr. Anat., Bd. 37, p. 192.

1893 Über den Graafschen Follikel, seine Entstehung beim Menschen und seine Schicksale beim Menschen und Säugetieren. Arch. f. mikr. Anat., Bd. 41, p. 219.

1914 Zur Theorie der Abderhalden'schen Schwangerschaftsreaktion, sowie Anmerkungen über die innere Sekretion des weiblichen Genitales. Erwägungen auf morphologischer Grundlage. Zentralbl. f. Gynaek., Jahrgang 38 , p. 425.

Schulin, K. 1881 Zur Morphologie des Ovariums. Arch. f. mikr. Anat., Bd. 19, p. 442.

Scott, W. J. M. 1916 Experimental mitochondrial changes in the pancreas in phosphorus poisoning. Am. Jour. Anat., vol. 20, p. 237.

Seitz, L. 1906 Die Follikelatresie während der Schwangerschaft, insbesondere die Hypertrophie und Hyperplasie der Theca-interna-Zellen (Theca-lutein-Zellen) und ihre Beziehungen zur Corpus luteumbildung. Arch. f. Gynaek., Bd. 77, p. 203.

De Sinety, L. 1877 De l'ovaire pendant la grossesse. Compt. Rend. de l'Acad. d. Sci., Paris, T. 85, p. 345.

Tandler, J. und Grosz, S. 1911 Über den Saisondimorphismus des Maulwufhodens. Arch. f. Entw. der Organ, Bd. 33, p. 297.

1913 Die biologischen Grundlagen der sekundären Geschlechtscharaktere. Berlin.

Tourneux, G. 1879 Des cellules interstitielles de l'ovaire. Journ. de l'Anat. et de la Physiol., T. 15, p. 305. 
Van der Stricht, O. 1901 L'atrésie ovulaire et l'atrésie folliculaire du follicule de Graaf, dans l'ovaire du chauvesouris. Verh. d. Anat. Gesell. zu Bonn, p. 108.

_._ 1912 Sur le processus de l'excrétion des glandes endocrines: Le corps jaune et la glande interstitielle de l'ovaire. Arch. de Biol., T. 27, p. 585.

Wagener, G. R. 1879 Bemerkungen über den Eierstock und den gelben Körper. Arch. f. Anat. u. Entw. (Reichert's A rrhiv), p. 175.

Wallart. iT. 1907 Untersuchungen über die interstitielle Eierstonksdrüse beim Menschen.' Arch. f. Gynaek., Bd. 81, p. 971 .

1908 Untersuchungen über das Corpus luteum und die interstitielle Eierstockdrüse während der Schwangerschaft. Zeitschr. f. Geburtsh. u. Gynaek., Bd. 63, p. 520.

Wheelon. H. 1917 The internal secretion of the testis. Interst.ate Med. Jour. (St. Louis), vol. 24, p. 1089.

Whitehead, R. H. 1912 On the chemical nature of certain granules in the interstitial cells of the testis. Am. Jour. Anat., vol. 14, p. 63 .

Von Winiwarter, H. 1908 Das interstitielle Gewebe der menschlichen Ovarien. Anat: Anz., Bd. 33, p. 1.

1912 Observations cytologiques sur les cellules interstitielles du testicule humain. Anat. Anz., Bd. 41, p. 309.

Von Winiwarter, H. et Sainmont, G. 1908 Über die ausschliesslich postfetale Bildung der definitiven Eier bei der Katze. Anat. Anz., Bd. 32, p. 613.

Wolz, Elisabeth 1912 Untersuchungen zur Morphologie der interstitiellen Eierstocksdrüse des Menschen. Arch. f. Gynaek., Bd. 97, p. 131.

Zalla, M. 1907 Ricerche sopra la struttura e l'istogenesi della sostasnza midollare dell'ovaia. Arch. Ital. d. Anat. e d. Embr., vol. 6, p. 706 . 


\section{Plate 1 \\ EXPLANATION OF FIGURES}

1. Photograph of longitudinal section of ovary of active adult woodchuck; just before hibernation (Oct. 26). Meves' acetic-osmic-chromic fixer, 10 miera, no stain, no cover. $X 7$. Shows distribution of interstitial cells, which are co-extensive with the blackened lipoid, which is unusually abundant for this time of the year.

2. Photograph of adult ovary, comparable to figure 1 in thickness, plane of section and technique. $X 7$. Animal taken from normal habitat while dormant. Typical ovary of late hibernation (Feb. 25). Shows an increase in interstitial tissue as judged from the amount of lipoid.

3. Photograph, comparable to figures 1 and 2, showing extreme hypertrophy of interstitial cells as met with late in the rutting season (last of April and first of May). X 7. Somewhat greater development than normally occurs at the beginning of pregnancy earlier in the season. CL are young corpora lutea. $\mathrm{CL}^{\prime}$ are corpora lutea of earlier ovulation not followed by pregnancy.

4. Photograph of area outlined in white in figure 3 under higher magnification. $X 30$. Shows the extent of lipoid-laden interstitial cells in the stroma.

5. Photograph comparable in every way to figures 1,2 and 3 , showing in black the characteristic interstitial cell content of late pregnancy and early lactation (May 8). X 7 .

6. Photograph of typical ovary of midsummer (July 28) after interstitial cells have nearly reached a minimum. Shows characteristic fatty content of corpora lutea just before they commence rapidly to disappear. Same technique as in figures $1,2,3$ and $5 . \times 7$.

7. Photograph of typical ovary of late summer when interstitial cells are minimal in size and number and almost free from lipoid. The single dark area is the remains of a corpus luteum which has not yet entirely disappeared. Same technique as other general views in this plate. Aug. 30. X 7 .

8. Photograph of ovary of adult animal isolated in captivity till May 18 , showing the small size of the ovary and the relative amount of interstitial tissue in females kept in captivity during the spring. Comparable to other general views in this plate. $X 7$.

9. Photograph showing migration of interstitial cells (identifiable by their black lipoid content and indicated by the arrow, which also shows the direction of movement) with neighboring stroma into a portion of a young corpus luteum. A portion of the corpus hemorrhagicum (CH) is present. Same technique as in preceding figures. $\mathrm{X} 60$.

10. Photograph showing relation of interstitial cells (dark areas) to vascular channels, which appear as prominent light areas because the blood has been washed out. In the center of each interstitial cell mass is usually a medullary cord. Zenker's with only 4 drops of acetic acid per 100 c.c., 5 micra, copper hematoxylin. X 45 . 

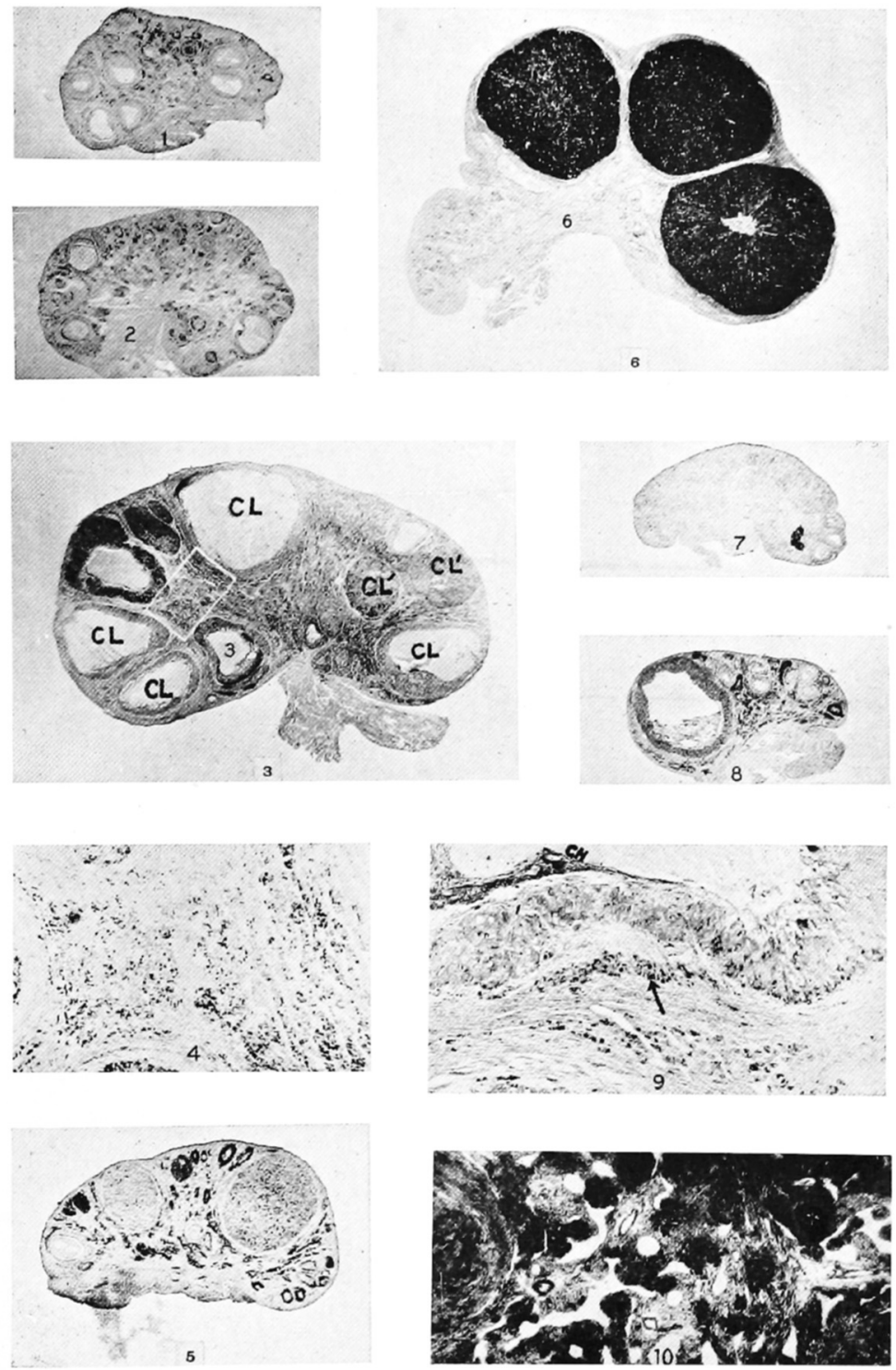
Plate 2

\section{EXPLANATION OF FIGURES}

11. Photograph of ovary of pregnant woodchuck (foetuses $40 \mathrm{~mm}$. to $45 \mathrm{~mm}$. in length). Shot in the field April 17. Zenker's, 10 micra,' iron liematoxylin. X 67 . Shows general view of cortex where cells appear to enter the ovary from the germinal epithelium.

12. Photograph of portion of figure 11 under higher magnification. X 333.

13. Photograph of peripheral portion of section of ovary of old adult showing cells leaving germinal epithelium. Early autumn (Sept. 5). The uninterrupted portion of the tunica albuginea is marked $T$. Carnoy's, 4 micra, iron hematoxylin. X 333.

14. Photograph of another portion of same section as figure 13 showing tunica albuginea apparently interrupted by cells from the germinal epithelium passing through it. A mitotic figure is seen at $M$. $X 333$.

15. Photograph of portion of adult ovary, in which the corpora lutea are rapidly being absorbed and many follicles are developing (Aug. 16), showing close relation of cells with oval and hyperchromatic nucleus to young follicles. Carnoy's, 3 miera, iron hematoxylin. X 333.

16. Photograph of medullary stroma of adult ovary as it appears in early autumn, showing relatively few cells with round vesicular nuclei. Carnoy's 4 micra, iron hematoxylin. $\mathrm{X} 200$.

17. Photograph of medullary stroma of adult ovary as it appears at the close of hibernation (Mar. 18). Animal sacrificed within 48 hours after waking up. To be compared with figure 16. Shows a noticeable increase in size and number of round nuclei (nuclei of interstitial cells). Carnoy's, 4 micra, iron hematoxylin. $\mathrm{X} 200$.

18. Photograph of medullary stroma of adult ovary when interstitial cells are maximal. Note large size of cells and vesticular nuclei. Carnoy's, 4 micra, iron hematoxylin. $\mathrm{X} 200$. 

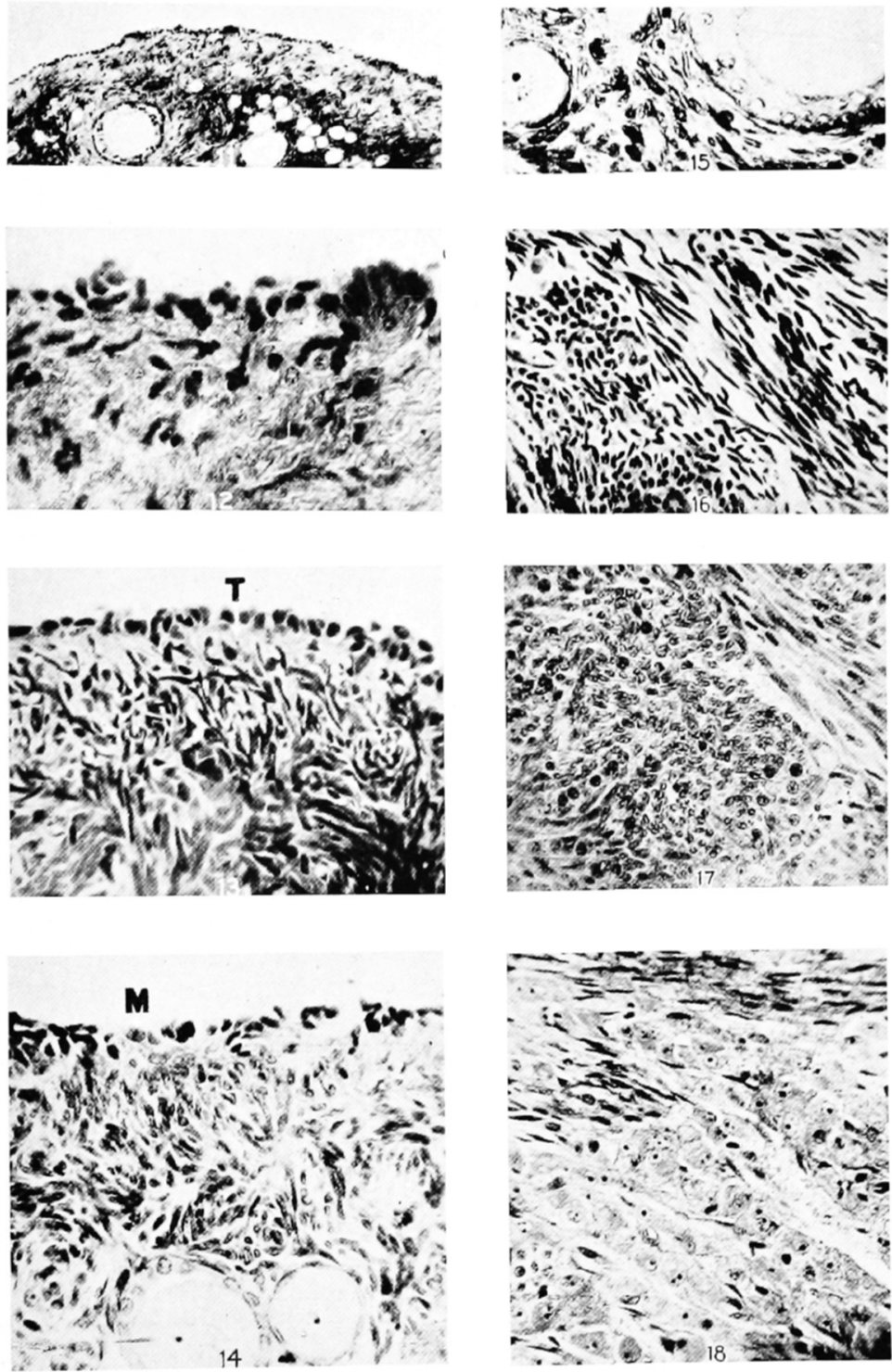


\section{EXPLANATION OF FIGURES}

19. Camera lucida drawing of stroma of adult ovary showing transitional stages between elongated cells (free from fatty globules, with hypercromatic nucleus and with but little cytoplasm which is difficult to demonstrate) and typical interstitial cells with lipoid-laden cytoplasm (indicated as vacuoles) and round vesicular nucleus. Zenler's with only 4 drops of acetic acid per 100 cc., 4 micra, iron hematoxylin. $X 800$. a, early indications of cytoplasmic increase. Solid stained nuclei are lymphocytes.

20. Photograph of a corpus luteum-like structure still containing an ovum (0). Early pregnancy (uterine enlargements $8 \mathrm{~mm}$. to $9 \mathrm{~mm}$. in diameter, April 27). Zenker's, 10 miera, iron hematoxylin. X 30.

21. Camera lucida drawing of portion of adult ovary during midsummer when corpora lutea (CL) are degenerating, showing characteristic down growths of germinal epithelium, giving rise to the irregular masses and cords of cells shown in the region marked $C$. Tunica albuginea is dark. $\mathrm{X} 500$.

22. Photograph of atretic follicle and adjacent stroma when interstitial cells (IC) are maximal, $M$ indicates the basement membrane of the granulosa and $\mathbf{T}$ the theca interna. Lipoid is black. Acetic-osmic-chromic fixer, 5 micra, acid fuchsin, no cover. $\mathrm{X} 44$.

23. Camera lucida drawings, showing certain nuclear characteristics. Carnoy's, 5 micra, iron hematoxylin. $a$ and $b$ are from the germinal epithe. lium of pregnant female and show what might be regarded as indications of direct cell division, but which is believed to be merely a folding. $\mathrm{X} 1000$. $\mathrm{c}$ is a section through cell cord newly derived from the germinal epithelium, showing the tendency for the nuclei to fold and twist. $X 1000$. $d, e, f, g, h$ and $i$ are cells encountered in the stroma esnecially in midsummer, showing a variety of forms they may assume. Nucleus is gran. ular and hyperchromatic. Appear to have been derived from the germinal epithelium and may transform into typical interstitial cells. X 1500 . 

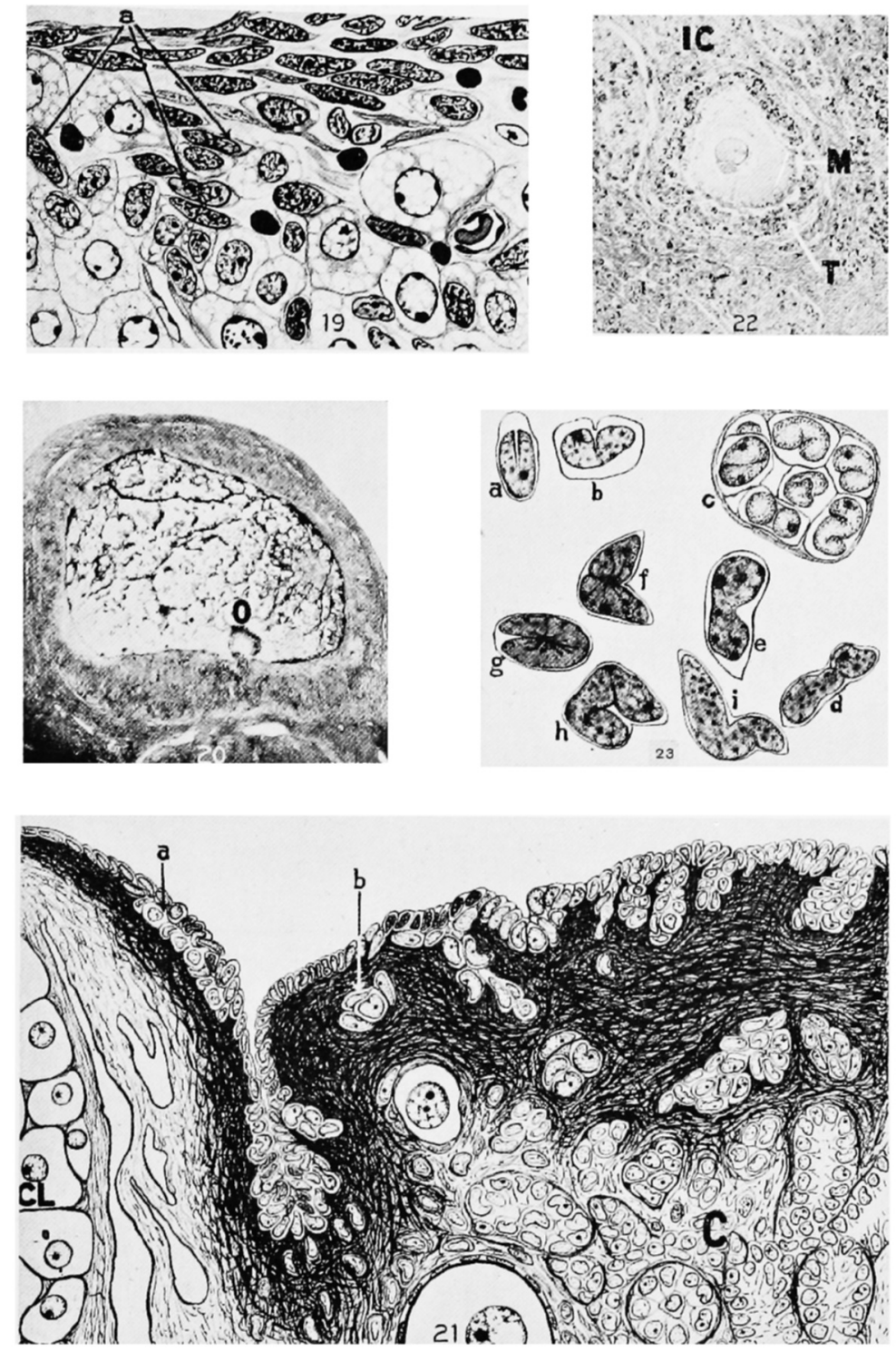


\section{EXPLANATION OF FIGURES}

All figures in this plate X 1000. Acetic-osmic-chromic or neutral formalin-dichromate fixation, 3 micra, acid fuchsin and methyl green stain. Large fatty globules appear black or as vacuoles. Mitrochondria and largel (secretion?) granules are red. Nucleolus either blue or red.

24. Types of interstitial cells of ovary in autumn before hibernation. a and $c$ are transitional stages between elongated cells in the stroma and typical interstitial cells. Red granules are mitochondria.

25. Largest interstitial cells of ovary found immediately after waking up from hibernation. $a$ is an intermediate stage between cells of figure 24 and of figure 26 . Note appearance of a few red granules distinctly larger than mitochondria.

26. Interstitial cells of ovary at maximum hypertrophy during spring. a is a group of four cells with indistinct boundaries. Note numerous large and intermediate fuchsinophil granules.

27. Successive stages in atrophy of interstitial cells of ovary (late spring and early summer).

28. Interstitial cell (of ovary) that has survived atrophy (midsummer).

29. Lutein cell for comparison with interstitial cells. Shows typical granular cytoplasm.

30. Intermediate stages between ordinary stroma cells and interstitial cells of ovary.

31. Stages in degeneration of lutein cells for comparison with interstitial cells.

32. Interstitial cells of testis as they are in autumn. b contains three pigment granules, one yellow (natural color), one red and one blue. Pigment in $\mathrm{c}$ is blue. p is a "pigment cell," showing nucleus crowded to lower border of cell and cytoplasm filled with pigment granules, which are mostly blue, four red, one orange and four yellow (natural color) stained red only on the surface. Shows coalescence of smaller granules to form larger ones. Mitochondria appear as small red granules.

33. a is an interstitial cell of testis in early stage of spring hypertrophy. $p$ is a pigment cell of this stage. Fatty globules appear as vacuoles, pigment blue, mitochondria red.

34. a is an interstitial cell of testis duing maximum hypertrophy in spring and early summer. Pigment (blue) nearly absent. There are many fuchsinophil granules (red) and large fatty globules (vacuoles). The group arrangement often seen is indicated. $p$ is a pigment cell of this time of the year just before complete atrophy. Mitochondria red. Pigment blue.

35. Interstitial cells of testis during midsummer atrophy. b is destined to become a pigment cell as p of next figure. Newly formed pigment is blue. Small red granules are mitochondria.

36. Interstitial cells of testis just after atrophy (Aug. 5). a represents the majority and contains some pigment (blue) and mitochondria (red). $p$ is a newly formed pigment cell. Mitochondria are red and pig. ment is blue or yellow (natural color) stained only on the surface. Forma. tion of larger granules from coalescence of smaller ones is evident. 

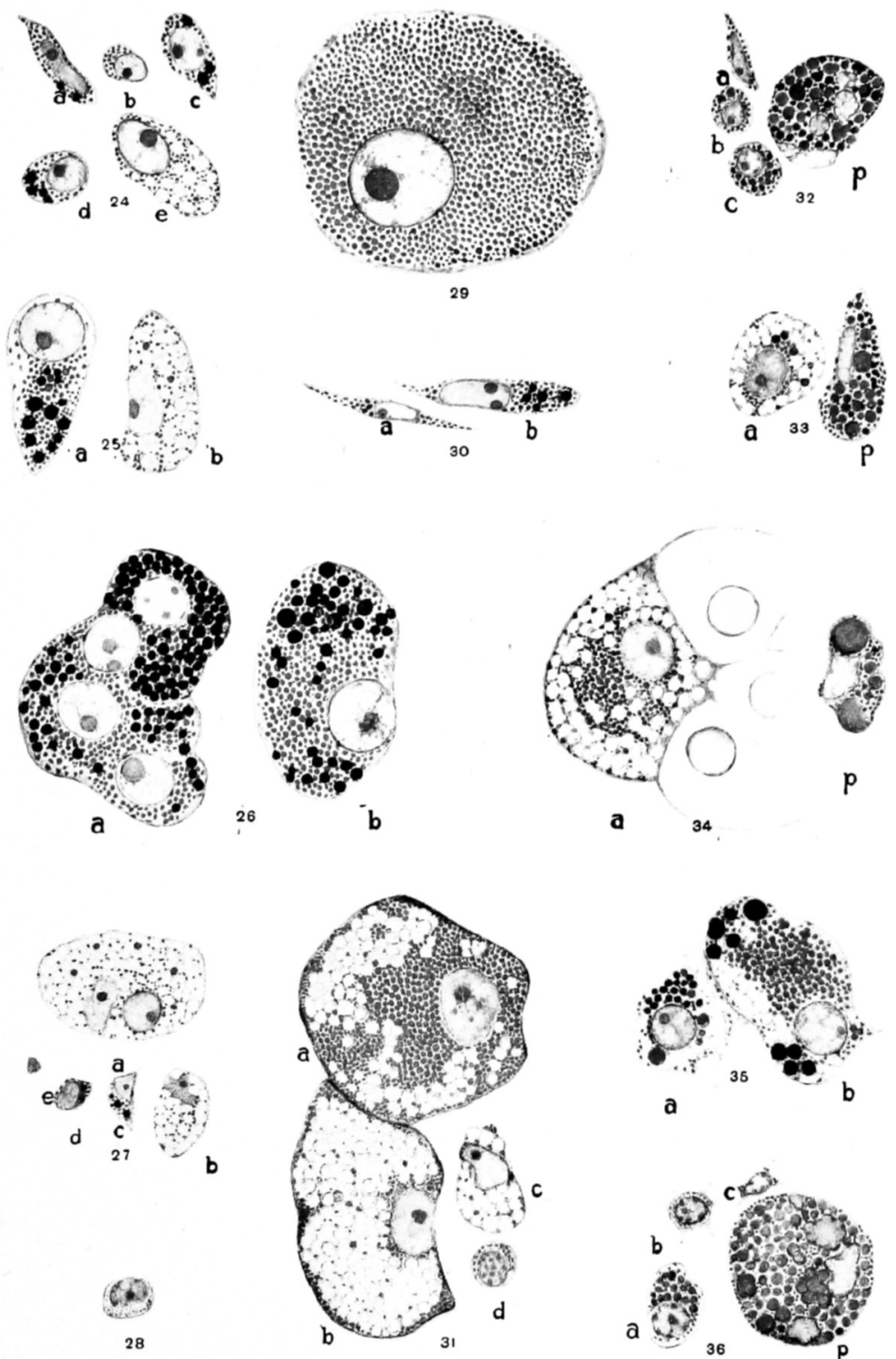

28

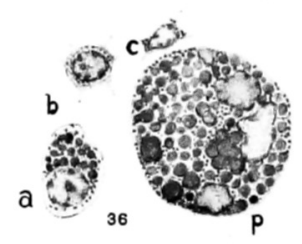

